DOI: 10.32089/WBH.PHW.2020.4(274).0003

orcid.org/0000-0002-9820-6140

BARTOSZ KAPUŚCIAK

(Oddziałowe Biuro Badań Historycznych

Instytutu Pamięci Narodowej w Katowicach)

\title{
Wallka kontirwywiadu wojskowego \\ z Kościołem katolickim. Alumni \\ w „ludowym” Wojsku Polskim w świetle dokumentów Wojskowej Służby Wewnętrznej
}

[...] przeciwnik jest groźny i wymaga z naszej strony stałej czujności i systematycznego rozpoznania.

płk Marian Ziółkowski ${ }^{1}$

Tajnych współpracowników rekrutujących się spośród alumnów zaliczamy do cennej agentury. ppłk Adolf Sieradzki

Kościół katolicki jawił się komunistom jako wróg ideologiczny, którego trzeba maksymalnie osłabić. Przejawy aktywnej działalności duszpasterskiej i kulturalnej Kościoła były drugim czynnikiem obok ideologii, który komuniści sukcesywnie zwalczali. To powodowało stosowanie przez nich różnych form represji i zastraszania. Powołanie kleryków do zasadniczej

1 Cyt. Archiwum Instytutu Pamięci Narodowej (dalej: AIPN), Szefostwo Wojskowej Służby Wewnętrznej (dalej: SWSW), 2386/21089, Wystąpienia szefa Wydziału WSW 6. PDPD w Krakowie, płk. Mariana Ziółkowskiego, na odprawie krajowej, [Warszawa] 21 XII 1976 r., k. 69. Przebieg służby płk. Mariana Ziółkowskiego (ur. 1 V 1931 r. w Nietuliskach Dużych), zob. https://katalog.bip.ipn.gov.pl/informacje/109267 (dostęp 15 IX 2020 r.).

2 Cyt. AIPN, SWSW, 2386/30839, Ppłk. Adolf Sieradzki, „Praca kontrwywiadowcza wśród alumnów powołanych do wojska, Oddział Kadr i Szkolenia Szefostwa WSW", Warszawa, styczeń 1964 r., s. 23. Przebieg służby płk. Adolfa Sieradzkiego (ur. 24 II 1925 r. w Piaskach), zob. https://katalog.bip.ipn.gov.pl/informacje/66653 (dostęp 15 IX 2020 r.). 
służby wojskowej było odpowiedzią wobec rzekomej „nieprzejednanej wrogości Kościoła wobec ludowego Państwa"3. Władza uważała, że to Kościół katolicki atakuje ideologię komunistyczną i aparat partyjny PRL ${ }^{4}$. Do $1959 \mathrm{r}$. rozpracowanie środowiska wojskowego (kadry i jej rodzin) oraz separowanie jej od związków z Kościołem katolickim było jednym z głównych celów Głównego Zarządu Politycznego Wojska Polskiego (GZP WP) i Głównego Zarządu Informacji (GZI), a po przeformowaniu w 1957 r. - Wojskowej Służby Wewnętrznej (WSW). Waga wyzwania wzrosła, gdy w 1959 r. zaczęto powoływać alumnów do wojska ${ }^{5}$. GZP WP i WSW musiały zewrzeć szeregi, by podołać ideologicznej walce z klerykami-żołnierzami, a przez to i z całym Kościołem katolickim w Polsce Ludowej.

\section{Stan zachowania dokumentów}

Niewielka jest liczba zachowanych dokumentów pokazujących zakres represji organów WSW wobec Kościoła katolickiego. Materiały takie w większości, podobnie jak te dotyczące „Solidarności”, zostały w 1989 r. zniszczone na rozkaz ostatniego szefa WSW, gen. bryg. Edmunda Buły ${ }^{6}$. Przetrwały jednak meldunki szefa WSW przygotowane dla szefa Głównego Zarządu Politycznego i ministra obrony narodowej, nieliczne normatywy, materiały operacyjne (w tym teczka obiektu 56 Szkolnego Batalionu Ratownictwa Terenowego w Brzegu) oraz opracowania wewnątrzresortowe, w których pojawia się wątek kościelny. Zachowały się też nieliczne dokumenty Departamentu IV

3 Cyt.: AIPN, Ministerstwo Spraw Wewnętrznych (dalej: MSW), 0639/231, t. 2, Notatka służbowa szefa GZP, gen. Wojciecha Jaruzelskiego, o sytuacji wśród alumnów wyższych seminariów duchownych, odbywających zasadniczą służbę wojskową, [Warszawa] 12 XII 1963 r., k. 18.

${ }_{4}$ Archiwum Akt Nowych, Komitet Centralny PZPR, V/59, Pismo Komitetu Centralnego PZPR do egzekutyw Komitetów Wojewódzkich, Powiatowych i Miejskich PZPR w sprawie działalności Kościoła katolickiego, [Warszawa] lipiec 1958 r., k. 154-175.

5 Próbny pobór do wojska miał nastąpić już w 1955 r. Zob. A. Setlak, Stużba wojskowa alumnów WSD w PRL i jej ocena w wypowiedziach alumnów i kapłanów rezerwistów z 1970 r. Studium historyczno-socjologiczne na przykładzie Bartoszyc, Olsztyn 2002, s. 17. Setlak również sugeruje, że już w 1958 r. wcielono do wojska 93 kleryków (ibidem, s. 18). Zob. także dokument nr 1 [Warszawa, 4 kwietnia 1959. Odpis notatki wicedyrektora Urzędu ds. Wyznań, Jana Lecha w sprawie służby wojskowej kleru] [w:] A. Lesiński, Służba wojskowa kleryków w PRL (1959-1980), Olsztyn 1995, s. 74-76.

${ }^{6} \mathrm{Na}$ temat niszczenia materiałów przez organa WSW zob. R. Peterman, Niszczenie akt GZI $i$ WSW [w:] Niepodległość ma jeden kształt. Antoniemu Macierewiczowi w 70. rocznice urodzin, Warszawa 2018, s. 354-355; B. Kapuściak, Celowe niszczenie czy przepisowe brakowanie? Glosa w sprawie nieistniejących materiałów po Głównym Zarządzie Informacji $i$ Wojskowej Stużbie Wewnętrznej, „Przegląd Archiwalny Instytutu Pamięci Narodowej” 2018, t. 11, s. 33-48. 
MSW i jego terenowych jednostek dotyczące służby alumnów w wojsku. Materiały te można odnaleźć w Archiwum Instytutu Pamięci Narodowej w Warszawie. Pozostały także dokumenty po GZP WP, w których widoczna jest walka oficerów politycznych z Kościołem katolickim, próba zeświecczenia młodych kleryków lub wpłynięcia na nich, aby przeszli na ich stronę, ostatecznie najzwyklejsze gnębienie psychiczne i fizyczne alumnów w wojsku. Zachowane materiały po wojskowym pionie politycznym znajdują się obecnie w Centralnym Archiwum Wojskowym Wojskowego Biura Historycznego w Warszawie-Rembertowie ${ }^{7}$.

Brak jest jak do tej pory publikacji odnoszących się do działalności kontrwywiadu wojskowego wobec kleryków-żołnierzy, a wśród licznych opracowań naukowych oraz wspomnień samych alumnów z okresu ich służby wojskowej nie ma informacji na temat działalności organów WSW albo są one jedynie zdawkowe. Większość skupiła swoją uwagę na działaniach pionu politycznego wojska lub władz państwowych ${ }^{8}$. Wyjątek stanowi książka Andrzeja

7 K. Ciemięga, Alumni w Wojsku Polskim w latach 1959-1980 w świetle dokumentów Głównego Zarządu Politycznego Wojska Polskiego, „Biuletyn Wojskowej Służby Archiwalnej” 2006, nr 28, s. 252-266.

8 Zob. m.in.: Schowaj miecz. Obiekcje sumienia w sprawie służby wojskowej. Materiały z sympozjum irenologicznego w Łodzi-Łagiewnikach 17-19 listopada 1989 roku, red. S. C. Napiórkowski, W. Koc, Niepokalanów 1993; T. Fitych, Służba wojskowa alumnów w PRL, „Chrześcijanin w Świecie” 1994, nr 1/196, s. 119-135; T. Pióro, Alumni pod broniq (1959-1980), "Więź" 1997, nr 1, s. 137-143; Mundur i sutanna, red. S. Pawłowski, Kraków 1998; Jubileuszowe spotkanie bytych alumnów, którzy w latach 1959-1981 petnili służbę wojskową. Deo et patriae, Warszawa-Modlin, 17-18 października 1997 roku, Warszawa 1998; J. Myszor, Stużba wojskowa alumnów Wyższego Śląskiego Seminarium Duchownego w latach 1959-1979 [w:] Wojskowa służba śląskich duchownych w latach 1918-1980, red. Z. Kapała, J. Myszor, Katowice 1999, s. 161-176; T. Wawryszko, Klerycy w wojsku. Wspomnienia ze służby wojskowej 1971-1973, Skołyszyn 2002; A. Setlak, Stużba wojskowa...; P. Piotrowski, Stużba wojskowa kleryków na przykładzie 56. Batalionu Ratownictwa Terenowego w Brzegu (1966-1980) [w:] Represje wobec Kościoła katolickiego na Dolnym Śląsku i Opolszczyźnie 1945-1989, red. S. A. Bogaczewicz, S. Krzyżanowska, Wrocław 2004, s. 165-178; J. Janowski, Alumni-żolnierze. Elementy formacji seminaryjnej w świadomości alumnów-żotnierzy na podstawie analizy dokumentów osobistych, Świdnica 2007; P. Larysz, Stużba wojskowa alumnów Śląskiego Seminarium Duchownego w latach 1959-1978, Katowice 2009; Kompanie kleryckie w Wojsku Polskim 1959-1980. Materiały $z$ konferencji naukowej zorganizowanej w 5. Pułku Inżynieryjnym w Szczecinie-Podjuchach 8-9 września 2008 r., red. J. Kornek, T. Krawczak, J. Macholak, Szczecin 2009; S. Paszkowski, Służba wojskowa kleryków w latach 1959-1980. Jerzy Popiełuszko - alumn żołnierz, „Wrocławski Przegląd Teologiczny” 2010, nr 1, s. 175-180; A. Czwołek, Służba wojskowa alumnów w PRL (na przykładzie 54. Szkolnego Batalionu Ratownictwa Terenowego w Bartoszycach), „Klio” 2011, nr 3, s. 104-130; M. Celmer, Stużba wojskowa alumnów Wyższego Seminarium Duchownego w Płocku w latach 1965-1980. Zarys problemu, „Studia Płockie” 2012, t. 40, s. 289-299; S. Gabański, Dobrze! Zapiski kleryka - żołnierza (1965-1967), Kraków 2013; S. Bobulski, Klerycy - Marynarze. Westerplatte 1964-1966 na tle przemian Kościoła w Polsce po II wojnie światowej, Kraków 2013; W. Frątczak, Służba wojskowa alumnów diecezji włocławskiej jako forma represji wobec Kościoła, „Ateneum Kapłańskie” 2005, t. 144, z. 1 (575), s. 27-44; 
Lesińskiego, gdzie aspekt metod kontrwywiadu wojskowego wobec kleryków został opisany nieco szerzej, choć dalej niewystarczająco9. Artykuł ten stanowi próbę odtworzenia sposobu myślenia żołnierzy organów WSW i GZP WP. Nie wszystkie informacje opracowane przez oficerów kontrwywiadu wojskowego udało się zweryfikować. Autor przyjął datę 1959 r. jako początkową, gdyż wtedy organa WSW zainicjowały rozpracowywanie alumnów. Rok 1955 jako pierwszy, w którym nastąpił pobór alumnów i ewentualna praca operacyjna organów GZI wobec nich, nie został wzięty pod uwagę ze względu na nieodnalezienie materiałów na ten temat. Podobne zastrzeżenie dotyczy roku 1958, w którym alumni także mieli zostać powołani do wojska - wydarzenie to nie zostało jednak odzwierciedlone w aktach pozostałych po WSW.

\section{I etap: lata $1959-1964^{10}$}

W 1959 r., w związku z wprowadzeniem ustawy o powszechnym obowiązku wojskowym, zaczęto powoływać alumnów z seminariów diecezjalnych jak

idem, Służba wojskowa kleryków JW. 4413 w Bartoszycach w latach 1968-1970, Włocławek 2015; L. Wilczyński, Pobór kleryków do wojska jako forma represji władz komunistycznych wobec Kościoła katolickiego. Alumni-żołnierze archidiecezji poznańskiej, „Ecclesia. Studia z Dziejów Wielkopolski” 2017, t. 12, s. 173-207; Przed 50. laty. Wyrwani z seminariów. Alumni-Żołnierze Brzeg n. Odra 1967-1969, praca zbiorowa, Brzeg 2017; M. Kapłon, Stużba wojskowa kleryków Wyższego Seminarium Duchownego w Przemyślu jako jeden z elementów represji komunistycznych [w:] Kościót katolicki w Europie Środkowo-Wschodniej w obliczu dwóch totalitaryzmów (1917-1990), t. II, red. M. Krzysztofiński, J. Wołczański, Rzeszów-Lwów 2017, s. 133-182; J. Zając, Mundur zamiast sutanny, Kraków 2019.

9 A. Lesiński, Służba wojskowa..., s. 43-44, 148-149. Szerokiego omówienia pracy operacyjnej organów WSW wśród alumnów-żołnierzy brakuje także w monografii poświęconej tym organom, chociaż sam wątek służby kleryków w wojsku został tam poruszony. Zob. L. Kowalski, Krótsze ramię Moskwy. Historia kontrwywiadu wojskowego PRL, Warszawa 2017, s. 231-257.

10 Ksiądz Stanisław Paszkowski za ks. Tadeuszem Fitychem dzieli etapy kleryckiej służby na okresy 1959-1964, 1965-1972 oraz 1973-1980, z czego dwa pierwsze według sposobu wcielania alumnów do jednostek wojskowych. Etap trzeci traktuje jako schyłkowy, gdzie pobór kleryków do wojska był już znacznie mniejszy i w tym czasie likwidowano jednostki w Brzegu i Szczecinie; zob. S. Paszkowski, Stużba wojskowa..., s. 175-176. Zob. także: T. Fitych, Stużba wojskowa..., s. 121-123. Identycznego podziału na okresy dokonał Leszek Wilczyński, zob. L. Wilczyński, Pobór kleryków..., s. 185-191. Inny podział sugeruje Adolf Setlak: 1955-1963 (pierwsze wcielenia kleryków w „diasporze”), 1964 (okres przejściowy) oraz 1965-1980 (alumni skoszarowani w szkolnych batalionach ratownictwa terenowego - SBRT); zob. A. Setlak, Służba wojskowa..., s. 32-34. Ks. Setlak był opiekunem alumnów w Bartoszycach. O jego wpływie na alumnów zob. AIPN, SWSW, 2386/21108, Informacja Szefostwa Wojskowej Służby Wewnętrznej, Warszawa 14 III 1980 r., k. 362-363; 2386/21089, Informacja [płk. Stanisława Sasa, szefa Zarządu WSW WOW] o nastrojach i przebiegu służby alumnów odbywających zasadniczą służbę wojskową w 54. szkolnym batalionie ratownictwa terenowego w Bartoszycach w okresie 28 X 1974-30 IV 1975 r., [Warszawa] 13 V 1975 r., k. 37-38 oraz Pismo nr B-02013 zastępcy szefa Zarządu WSW POW, płk. Antoniego Kubickiego do szefa Zarządu 
i zakonnych do wojska, początkowo rozpraszając ich po różnych jednost$\mathrm{kach}^{11}$. Pierwszych 71 alumnów powołano z seminariów w Kielcach ${ }^{12}$, Przemyślu, Tarnowie i Płocku, następną grupę, także w liczbie 71 osób, powołano w 1960 r. z seminariów w Kielcach, Tarnowie i Płocku, kolejną w 1961 r., w liczbie 52 alumnów, z seminariów w Kielcach, Przemyślu, Gorzowie Wielkopolskim, Gościkowie, Gnieźnie, Krakowie, Starej Wsi, Lublinie, Łodzi i Częstochowie. W kolejnym roku powołano aż 176 alumnów z seminariów w Gnieźnie, Kielcach, Przemyślu, Krakowie, Wrocławiu, Poznaniu, Nysie, Gościkowie, Olsztynie oraz z niższego seminarium w Gliwicach ${ }^{13}$. W 1963 r.

II Szefostwa WSW, Bydgoszcz 25 X 1978 r., k. 106-107. Przebieg służby płk. Stanisława Sasa (ur. 5 XII 1930 r. w Borysławiu) zob. https://katalog.bip.ipn.gov.pl/informacje/69232 (dostęp 15 IX 2020 r.); płk Antoniego Kubickiego (ur. 4 II 1926 r. w Opatowie Częstochowskim) zob. https://katalog.bip.ipn.gov.pl/informacje/69648 (dostęp 15 IX 2020 r.).

11 Ustawa z dn. 30 I 1959 r. o powszechnym obowiązku wojskowym (Dz.U. 1959, nr 14, poz. 75). Zając podaje, że do wojska wcielano alumnów także w 1958 r.; zob. J. Zając, Mundur zamiast..., s. 17. Podobnie J. Marecki, Katolicy polscy pod rządami komunistów [w:] S. Gabański, Dobrze! Zapiski..., s. 26-27. Zob. też opracowane przez Józefa Mareckiego tabele dot. poboru alumnów do wojska zaczerpnięte od Setlaka: ibidem, s. 28, 31-33; AIPN, SWSW, 2386/30713, Ppłk Henryk Kramek, „Wroga działalność kleru katolickiego w Polsce i oddziaływanie na wojsko", praca egzaminacyjna, Wyższy Kurs Doskonalenia Oficerów WSW - Wojskowa Akademia Polityczna, Warszawa maj 1962 r., s. 68-72. Przebieg służby płk. Henryka Kramka (ur. 10 VII 1927 r. w Braciejowicach) zob. https://katalog.bip.ipn.gov. pl/informacje/111806 (dostęp 15 IX 2020 r.). W tym czasie były też przypadki powołania uczniów niższych seminariów duchownych oraz nowicjuszy.

12 W tym czasie najwięcej, bo 45 alumnów, powołano z Wyższego Seminarium Duchownego (WSD) w Kielcach, co miało związek ze sprawą bp. Czesława Kaczmarka. Zob. AIPN, MSW, 0639/231, t. 2, Wnioski Wydziału Administracyjnego KC w sprawie powołania alumnów wyższych seminariów duchownych do zasadniczej służby wojskowej w roku 1963, Warszawa wrzesień 1963 r., k. 3. Na temat bp. Kaczmarka zob. J. Śledzianowski, Ksiądz Czesław Kaczmarek - biskup kielecki 1895-1963, Kielce 2008. Gdzie indziej mówi się o liczbie 71 powołanych, z czego z WSD w Kielcach miało wstąpić do wojska 46 alumnów. Zob. Centralne Archiwum Wojskowe Wojskowego Biura Historycznego (dalej: CAW-WBH), Główny Zarząd Polityczny Wojska Polskiego (dalej: GZP WP), 380/92/144, Notatka dot. powołanych do wojska byłych alumnów z seminariów duchownych, [Warszawa] 5 III 1960 r., k. 88. Pada też liczba 63 alumnów, z czego 40 z WSD w Kielcach, zob. P. Piotrowski, Służba wojskowa..., s. 165. Zawyżone dane tylko z seminariów diecezjalnych podaje w tabeli Setlak, niestety nie przywołuje źródeł, skąd zaczerpnął te dane; zob. A. Setlak, Stużba wojskowa..., s. 20. Jeszcze inne dane zob. idem, Wojskowa służba kleryków jako jeden ze sposobów zaplanowanej walki systemu socjalistycznego z Kościołem w Polsce [w:] Mundur i sutanna..., s. 278-279, 280-283.

13 AIPN, SWSW, 2386/30839, Ppłk Adolf Sieradzki, „Praca kontrwywiadowcza wśród alumnów powołanych do wojska, Oddział Kadr i Szkolenia Szefostwa WSW", Warszawa styczeń 1964 r., s. 8-9. W innym miejscu podano, że w 1961 r. powołano 51 alumnów, a w $1962 \mathrm{r}$. - 127 kleryków; zob. AIPN, MSW, 0639/231, t. 2, Wnioski Wydziału Administracyjnego KC w sprawie powołania alumnów wyższych seminariów duchownych do zasadniczej służby wojskowej w roku 1963, Warszawa, wrzesień 1963 r., k. 3. 
powołano do wojska 179 kleryków, a w kolejnym 160 lub $161^{14}$. W początkowym okresie celowo kierowano ich do pododdziałów, w których przeważali żołnierze niewierzący, co miało oddźwięk psychologiczny ${ }^{15}$.

Z pisma ówczesnego szefa WSW, Aleksandra Kokoszyna ${ }^{16}$, wynika, że organa kontrwywiadu wojskowego zaniedbały „ochronę” jednostek przed księżmi, którzy kontaktowali się z wojskowymi. Stąd jeszcze przed powołaniem alumnów organa WSW zainicjowały pracę operacyjną w jednostkach wojskowych i w ich otoczeniu, aby wykryć i „zabezpieczyć” księży, którzy wykazywali aktywność w działalności duszpasterskiej ${ }^{17}$. Przede wszystkim dotyczyło to duchownych z parafii wokól jednostek wojskowych, z którymi kontaktowali się żołnierze służby zasadniczej. Co jednak ważniejsze i groźniejsze dla komunistów, księża ci utrzymywali kontakt z rodzinami żołnierzy zawodowych ${ }^{18}$. Szczególnie „narażone” na kontakt były żony wojskowych, które zawsze wykazywały się większą religijnością, a co za tym idzie, pozwalały dzieciom uczęszczać na lekcje religii, chodziły z nimi na nabożeństwa, uczestniczyły w sakramentach. Działanie oficerów WSW skupione miało

${ }_{14}$ Zob. AIPN, MSW, 0639/231, t. 2, Notatka służbowa szefa GZP, gen. Wojciecha Jaruzelskiego o sytuacji wśród alumnów wyższych seminariów duchownych, odbywających zasadniczą służbę wojskową, [Warszawa] 12 XII 1963 r., k. 13; P. Piotrowski, Służba wojskowa..., s. 165. Z innych danych wynika, że w 1963 r. wcielono 158 alumnów, a w 1964 r. - 178. Zob. CAW-WBH, GZP WP, 380/92/743, Notatka służbowa zawierająca propozycje wprowadzenia w życie nowych zasad wcielania i przeszkalania w wojsku alumnów seminariów duchownych i zakonnych, [Warszawa] 2 XI 1964 r., k. 136. Z jeszcze innych danych wynika, że w 1959 r. wcielono do wojska 63 alumnów, w 1960 r. - 73, w 1961 r. - 86, w 1962 r. - 151, w 1963 r. - 160, a w 1964 r. - 164. Zob. AIPN, MSW, 0639/231, t. 2, Informacja [Urzędu ds. Wyznań i GZP WP] o politycznych i organizacyjnych wynikach powołań alumnów WSD do odbywania zasadniczej służby wojskowej w latach 1959-1964, [Warszawa] 26 IX 1964 r., k. 36. Różnice $\mathrm{w}$ danych wynikają z różnych powodów. Przede wszystkim w czasie odbywania służby dochodziło do zwalniania alumnów przez garnizonowe komisję lekarskie ze względu na zły stan zdrowia, a także do przedterminowych zwolnień ze służby ze względu na podjęcie świeckich studiów lub w ramach tzw. wyrównania rocznika dla wyróżniających się w służbie kleryków-żołnierzy. Odnotowano również przypadki niestawiania się alumnów na czas w jednostkach wojskowych. Zob. także: L. Wilczyński, Pobór kleryków..., s. 180-185.

${ }^{15}$ CAW-WBH, GZP WP, 380/92/144, Notatka dot. powołanych do wojska byłych alumnów z seminariów duchownych, [Warszawa] 5 III 1960 r., k. 89.

16 Biogram gen. bryg. Aleksandra Kokoszyna zob. Instrukcje pracy kontrwywiadowczej Wojskowej Stużby Wewnętrznej wraz z instrukcjami prowadzenia dokumentacji i ewidencji (1957-1990), wstęp i oprac. B. Kapuściak, Kraków 2010, s. 21-22; https://katalog.bip.ipn.gov. pl/informacje/60427 (dostęp 15 IX 2020 r.).

17 AIPN, SWSW, 2386/31261, Pismo szefa Wojskowej Służby Wewnętrznej nr BB-00993/3/59, [Warszawa] 4 III 1959 r., k. 155-157.

18 CAW-WBH, GZP WP, 380/92/144, Informacja dotycząca wpływu kleru na skład osobowy jednostek Pomorskiego Okręgu Wojskowego oraz przejawów klerykalizmu kadry niektórych garnizonów, [Warszawa] 19 IV 1960 r., k. 84-87. 
być na zapobieganiu kontaktom żołnierzy z księżmi miejscowych parafii. Drugą, nie mniej ważną sprawą dla organów WSW było rozpracowanie kapelanów wojskowych, ich stosunku do władz państwowych, ale przede wszystkim przyjrzenie się ich powiązaniom z kurią i z poszczególnymi księżmi. To pozwalało ocenić, na ile księża ci są lojalni wobec władz, szczególnie w okresie powoływania do wojska alumnów. Kolejnym, ważnym zadaniem oficerów WSW było zebranie drogą operacyjną - czyli poprzez kontakty poufne i agenturę - informacji na temat duchownych diecezji w miejscach, w których stacjonowały jednostki wojskowe. Szefostwo WSW chciało wiedzieć, jaki stosunek mają ci księża do kurii, do wyższego duchowieństwa i do władzy komunistycznej ${ }^{19}$.

Główne zadanie organów kontrwywiadu wojskowego od 1959 r. polegało jednak na rozpracowaniu młodych alumnów przybyłych do jednostek, z którymi od samego początku były „problemy”. Ci namawiali szeregowych żołnierzy, z którymi służyli w pododdziałach, do wspólnych modlitw oraz uczestniczenia $\mathrm{w}$ niedzielnych nabożeństwach. Środowisko alumnów było przeciwne służbie wojskowej, wiedząc, że ich powołanie do wojska jest próbą walki z Kościołem. Jeszcze bardziej niechętnie młodzi klerycy-żołnierze podchodzili do organów WSW. Stąd kontrwywiad wojskowy miał spore kłopoty z werbunkiem agentów wśród przyszłych księży - jeżeli nawet doszło ostatecznie do werbunku agenturalnego alumna, ten po odbyciu służby wojskowej często odmawiał on powrotu do seminarium. Zaznaczyć należy, że nie było to regułą. Organa WSW traciły wówczas agenturę cenną dla Departamentu III MSW i jego terenowych jednostek ${ }^{20}$. Nieumiejętność pracy operacyjnej organów WSW z tak „trudnymi” przypadkami jak przyszli księża spowodowała, że zawarto pierwsze porozumienie o współpracy służb wojskowych z cywilnymi ${ }^{21}$. W jego wyniku oficerowie Służby Bezpieczeństwa mogli uczestniczyć w werbunku kleryków i spotkaniach z agenturą spośród alumnów. Bezpieka pomagała także przy rozpracowaniach przyszłych księży

19 AIPN, SWSW, 2386/31261, Pismo szefa Wojkkowej Służby Wewnętrznej nr BB-00993/3/59, [Warszawa] 4 III 1959 r., k. 156.

20 Pion ten w latach 1956-1962 zajmował się walką z Kościołem; zob. Aparat bezpieczeństwa w Polsce. Kadra kierownicza, t. II: 1956-1975, red. P. Piotrowski, Warszawa 2006, s. 14.

21 AIPN, SWSW, 2386/31261, Pismo szefa Zarządu I Szefostwa WSW, płk. Teodora Kufla, i wicedyrektora Departamentu III MSW, ppłk. Stanisława Morawskiego, nr BB-02222/13/60, [Warszawa] 15 IV 1960 r., k. 157-158. Zob. także: A. Dziurok, Wstęp [w:] Metody pracy operacyjnej aparatu bezpieczeństwa wobec kościołów i związków wyznaniowych 1945-1989, red. A. Dziurok, Warszawa 2004, s. 23 oraz F. Musiał, Departament IV MSW w latach 1962-1989. Przyczynek do monografii [w:] Instrukcje, wytyczne, pisma Departamentu IV Ministerstwa Spraw Wewnętrznych z lat 1962-1989. Wybór dokumentów, red. i oprac. A. Dziurok, F. Musiał, Kraków-Katowice 2017, s. 37-41. Przebieg służby płk. Stanisława Morawskiego (ur. 19 X 1924 r. w Jakubowicach Murowanych) zob. https://katalog.bip.ipn. gov.pl/informacje/40054 (dostęp 15 IX 2020 r.). 
oraz typowaniach do werbunku. Bardzo pomocna miała być także wymiana informacji i materiałów operacyjnych dotyczących alumnów i księży ${ }^{22}$. Już po roku od powołania alumnów Szefostwo WSW zdało sobie sprawę, że z tych, których udało się zwerbować na agentów, większość po odbyciu służby wojskowej nie kontynuowała studiów w seminarium. Kadra kierownicza wojskowego aparatu represji wychodziła z założenia, że błędem jest niestawianie takim agentom zadań rozpracowywania środowiska alumnów - byli oni kierowani do ogólnej profilaktyki kontrwywiadowczej wśród stanu zmiennego jednostek. Powodowało to, że nawet jeśli ktoś z byłych współpracowników kontrwywiadu wojskowego powrócił jednak na uczelnię, odmawiał współpracy z SB. Pamiętać trzeba, że przy werbunku księży używano argumentu patriotycznego, który w „ludowym” wojsku był stale podkreślany. Patriota powinien współpracować z WSW, pomagać chronić wojsko przed szpiegami i dywersantami, informować kontrwywiad o podejrzeniach planowanych dezercji, szczególnie tych z bronią w ręku, niebezpiecznych również dla cywilów - tego typu argumenty trafiały do młodych ludzi ${ }^{23}$. Mówiąc o wojsku, zawsze podkreślano, że to „Wojsko Polskie”, które ma bronić „naszej ojczyzny”. Uwydatnianie polskości i powoływanie się na wspólnotę jako czynnik patriotyczny miało oddziaływać, solidaryzować, a ostatecznie skłaniać młodych ludzi do charakterystycznego w tym okresie myślenia, ignorującego genezę tego „odrodzonego” wojska i tego w jakim układzie militarnym ono się znajdowało ${ }^{24}$.

Podpułkownik Adolf Sieradzki sugerował więc, by obsadzać alumnów ściśle według zasady: nie więcej niż jeden alumn w batalionie, a w pułku nie więcej niż jeden alumn $\mathrm{z}$ tego samego seminarium. Przy tym zawsze otoczyć go tajnymi współpracownikami i kontaktami operacyjnymi, by w ten sposób zapewnić sobie „dopływ informacji” o nim, jednocześnie by takie osobowe źródła informacji wpływały na kleryka-żołnierza, pokazując mu wyższość życia świeckiego nad duchowym. Dodatkowo doświadczony oficer

22 AIPN, SWSW, 2386/31261, Pismo szefa Zarządu I Szefostwa WSW, płk. Teodora Kufla, i wicedyrektora Departamentu III MSW, ppłk. Stanisława Morawskiego, nr BB-02222/13/60, [Warszawa] 15 IV 1960 r., k. 157-158.

${ }^{23}$ Zob. Nr 2. 1957 czerwiec 21, Warszawa - Instrukcja o zasadach pracy kontrwywiadowczej w wojsku [w:] Instrukcje pracy kontrwywiadowczej..., s. 72; AIPN, SWSW, 2386/30839, Ppłk Adolf Sieradzki, „Praca kontrwywiadowcza wśród alumnów powołanych do wojska, Oddział Kadr i Szkolenia Szefostwa WSW”, Warszawa styczeń 1964 r., s. 21-22.

$24 \mathrm{Na}$ ten temat zob. chociażby: M. L. Krogulski, Okupacja w imię sojuszu. Armia Radziecka $w$ Polsce 1944-1956, Warszawa 2000; idem, Okupacja w imię sojuszu. Armia Radziecka w Polsce 1956-1993, Warszawa 2001; A. Skrzypek, Mechanizmy uzależnienia. Stosunki polsko-radzieckie 1944-1957, Pułtusk 2002; idem, Mechanizmy autonomii. Stosunki polsko-radzieckie 1956-1965, Pułtusk 2005; idem, Mechanizmy klientelizmu. Stosunki polsko-radzieckie 1965-1989, Pułtusk 2008; W. Jarząbek, PRL w politycznych strukturach Układu Warszawskiego w latach 1955-1980, Warszawa 2008; S. Cenckiewicz, Geneza Ludowego Wojska Polskiego 1943-1945, Warszawa 2017. 
GZI/WSW proponował, by próbować przeprowadzać kombinację operacyjną zmierzającą do ostatecznego zawerbowania kleryka, a polegającą na tym, że do jego wiadomości miała dotrzeć jakaś określona informacja, o której ten niezwłocznie powinien zameldować oficerowi kontrwywiadu, bądź tak zainspirować alumna, by ten sam zgłosił się z tą informacją do oficera WSW. $\mathrm{W}$ ten sposób próbowano wpłynąć na postawę kleryka, wyrobić w nim odruch „obywatelski”, czy nawet „patriotyczny” (oba rozumiane jednak przez Siły Zbrojne PRL dość specyficznie $)^{25}$.

Stąd ppłk Sieradzki radził, by do werbunku alumna dobrze się przygotować, studiując zebrane wcześniej na niego materiały (wychwycić argumenty świadczące o nieprzestrzeganiu przez niego prawa kanonicznego, łamaniu dyscypliny wojskowej czy obowiązujących zasad etycznych), posiłkując się także informacjami zebranymi przez SB. Także samo miejsce spotkania miało nie obrażać jego uczuć religijnych, a jednocześnie gwarantować konspirację. Rozmowa przed werbunkiem miała być luźna, niedotycząca spraw Kościoła czy religii, należało się raczej zorientować, jakie inne zainteresowania ma żołnierz-kleryk i w tę stronę poprowadzić rozmowę. Powinno się także namówić alumna, aby wszelkie podane informacje dotyczące zdarzeń w jednostce napisał odręcznie lub szczegółowo opowiedział. Dobrze też, jeżeli podczas werbunku kleryk chciał podpisać zobowiązanie, ale nie była to konieczność (bardziej zwracano uwagę, by TW pisali odręczne meldunki). Przy werbunku i współpracy należało zawsze powoływać się na takie argumenty, jak: „obowiązek walki ze złem, reagowanie na krzywdę wyrządzoną słabszym, obrona ojczyzny przed wrogiem zewnętrznym i wewnętrznym”. W pierwszym etapie współpracy ppłk Sieradzki proponował skupić zadania TW wywodzącego się z alumnów na zwykłych niedociągnięciach w pododdziale, kradzieżach, szykanowaniu żołnierzy. Dopiero gdy nabierze się przekonania o szczerości żołnierza-kleryka, powinno się ukierunkowywać go na „zadania poważniejsze o charakterze politycznym”. Za dobre wykonanie zadania oficer kontrwywiadu proponował pomoc alumnowi w drobnych sprawach, jak przeniesienie na inne stanowisko, załatwienie urlopu lub przepustki, a nawet nagradzanie małymi sumami pieniędzy, rzędu 100-200 zł. Należało także ciągle podkreślać wobec kleryka wyższość „życia w cywilu”, sugerować możliwości załatwienia przeniesienia $\mathrm{z}$ seminarium na inną uczelnię świecką czy pomoc w znalezieniu pracy, czyli wszystkie te propozycje, jakie propagował wówczas GZP WP ${ }^{26}$.

Z czasem, w wyniku zaostrzającej się walki z Kościołem katolickim, pion polityczny wojska wnioskował do kierownictwa PZPR o zwiększenie

25 AIPN, SWSW, 2386/30839, Ppłk Adolf Sieradzki, „Praca kontrwywiadowcza wśród alumnów powołanych do wojska, Oddział Kadr i Szkolenia Szefostwa WSW", Warszawa styczeń 1964 r., s. 15-16, 18-19.

${ }^{26}$ Ibidem, s. 19-24. Stamtąd też cytaty. 
limitów poboru przyszłych duchownych. W latach 1959-1965 powoływanie żołnierzy-kleryków miało charakter - jak twierdziło samo Szefostwo WSW - represyjny. Tym bardziej, że alumnów powoływano do wojska głównie z diecezji kierowanych przez tych hierarchów, wobec których władze komunistyczne miały zastrzeżenia. Ze względu na liczne pogadanki polityczne zorganizowane przez GZP WP i WSW część młodych ludzi zrezygnowała $\mathrm{z}$ dalszej nauki w seminariach po wyjściu z wojska. Kościół postanowił aktywnie włączyć się wobec tego w walkę z GZP WP i przygotowywać przyszłych alumnów do odpierania ataków na Kościół podczas spotkań „wychowawczych" z oficerami politycznymi. Według dokumentów wytworzonych przez WSW to hierarchia kościelna zleciła opracowanie materiałów, które miały pomóc odeprzeć argumenty oficerów politycznych. Takie szkolenia alumnów udających się do wojska przez poszczególne seminaria miało zapobiec rezygnacjom ze studiów duchownych. Kościół zatroszczył się też o kontakty alumnów z proboszczami parafii, które znajdowały się w pobliżu jednostek wojskowych. Miejscowi księża mieli wspierać duchowo młodych kleryków poprzez organizowanie nabożeństw i spotkań. Także nauczyciele seminaryjni prowadzili z nimi korespondencję, a hierarchowie odwiedzali ich w jednostkach wojskowych. Wobec troski Kościoła katolickiego o przyszły stan duchowny i przygotowane argumenty teologiczne wojskowy pion polityczny postanowił opracować „naukową” odpowiedź, jednocześnie uczulał organa WSW, aby alumnom zabierać wszelkie materiały dotyczące spraw kościelnych i religijnych opracowane przez seminaria ${ }^{27}$. W materiałach tych (prawdopodobnie były to skrypty do nauki i wykładów) występowały najczęściej zagadnienia dotyczące historii Kościoła katolickiego (inkwizycja, indeks ksiąg zakazanych, podejście Kościoła do niektórych dziedzin nauki, stosunek papieży Piusa XII do Polski czy Grzegorza XVI do powstania listopadowego), teologii (dowody na istnienie Boga, religie na świecie, cuda), poruszano także tematy krytyczne wobec samej instytucji ówczesnego Kościoła katolickiego i jego nauczania (antykoncepcja, celibat, stosunki płciowe przed ślubem, modlitwa za pieniądze). Wojskowa Służba Wewnętrzna ubolewała, że z zarekwirowanych materiałów wynika, iż „kler przestudiował uważnie niektóre kierunki pracy ateistycznej i politycznej wobec alumnów” i, co więcej, zawarte w niej argumenty próbuje „przenosić [...] poprzez kleryków na otoczenie"28. Nie tylko alumni byli odpowiednio przeszkoleni w walce słownej z dowódcami i oficerami politycznymi jednostek wojskowych, ale

${ }^{27}$ Ibidem, 2386/31261, Pismo zastępcy szefa Wojskowej Służby Wewnętrznej, płk. Teodora Kufla nr BB-06854/10/63, [Warszawa] grudzień 1963 r., k. 159-161; Pismo zastępcy szefa Wojskowej Służby Wewnętrznej, płk. Teodora Kufla nr BB-0564/10/63, [Warszawa] 31 I 1963 r., k. 162-166.

28 Ibidem, Pismo zastępcy szefa Wojskowej Służby Wewnętrznej, płk. Teodora Kufla nr BB-06854/10/63, [Warszawa] grudzień 1963 r., k. 160-161. Stamtąd cytaty. Zob. też ibidem, 
swoją postawą i twierdzeniami byli w stanie przekonać zwykłych żołnierzy, a to, według GZP WP i WSW, stanowiło zagrożenie dla trzonu i spójności ideologicznej całego wojska.

Kościół katolicki w trosce o alumnów wysyłał do jednostek wojskowych miejscowych proboszczów, przesyłał paczki na święta, ale także nakazywał klerykom wzajemne pilnowanie się i solidaryzowanie, co miało zapobiegać wykruszaniu się tych najsłabszych psychicznie. Wobec tego alumni zbierali się na wspólne czytanie listów z seminariów, modlitwy, naukę. Próbowali także często symulować choroby, co jednak spotykało się z karami dyscyplinarny$\mathrm{mi}^{29}$, bądź nawet dezerterować ${ }^{30}$. W odpowiedzi na takie stanowisko Kościoła katolickiego wobec kleryków płk Teodor Kufel ${ }^{31}$ nakazał by nie dopuszczano do spotkań księży z alumnami i starano się wykorzystać „postępowy kler”

Pismo zastępcy szefa Wojskowej Służby Wewnętrznej, płk. Teodora Kufla nr BB-06929/17/62, [Warszawa] 3 XI 1962 r., k. 166-167.

29 Ibidem, Pismo zastępcy szefa Wojskowej Służby Wewnętrznej, płk. Teodora Kufla nr BB-0564/10/63, [Warszawa] 31 I 1963 r., k. 163-165; Pismo zastępcy szefa Wojskowej Służby Wewnętrznej, płk. Teodora Kufla nr BB-01124/10/63, [Warszawa] 3 II 1963 r., k. 167-168.

30 Znany jest tylko jeden przypadek dezercji szer. Jerzego Wąsowicza, alumna z WSD we Wrocławiu służącego w 5 Pułku Artylerii w Chełmie Lubelskim (JW 1991), z którego zdezerterował 6 VI 1963 r. ze względu na szykany jakie go dotknęły w jednostce. Wcześniej odbywał karę czternastodniowego aresztu zwykłego. Ujęty został 20 VIII 1963 r. i skazany 5 XII tr. przez Sąd Warszawskiego Okręgu Wojskowego (WOW) na półtora roku więzienia. Zob. ibidem, 2386/10811, Sprawa Operacyjnego Poszukiwania nr 489 dot. dezercji bez broni krypt. „Kleryk” [1963-1964]. W dniu 11 XII 1964 r. zarejestrowany przez Oddział WSW Lublin jako informator ps. „Grzegorz” do nr 11810. Prowadzony później przez Oddział WSW Wrocław. Zob. AIPN, SWSW, 003200/1, Centralny rejestr agentury i właścicieli lokali konspiracyjnych WSW nr 1-12949 [1957-1966], k. 457; 2386/10810, Teczka personalna nr 11810 tajnego współpracownika ps. „Grzegorz” [1964-1988]. Po ucieczce Wąsowiczem zaopiekował się ks. Czesław Andrzejuk, który dał mu pieniądze i ubrania cywilne. Za pomoc alumnowi został skazany 5 XII 1963 r. przez Sąd WOW na osiem miesięcy pozbawienia wolności w zawieszeniu na dwa lata. Czesław Andrzejuk został 10 VII 1967 r. zarejestrowany przez Wydział IV KWMO w Lublinie do ewidencji operacyjnej księży i był rozpracowywany w ramach teczki ewidencji operacyjnej na księdza (TEOK). W dniu 29 VI 1977 r. pozyskany w kategorii tajnego współpracownika ps. „Maciej” przez Wydział IV KWMO w Białej Podlaskiej. Materiały zakończono w 1989 r. ze względu na „odmowę współpracy” i złożono do nr I/2311, a w 1990 r. miano zniszczyć. Zachowały się jednak. Zob. AIPN, MSW, 2911/1, Karta o symbolu Mkr-2 z kartoteki ogólnoinformacyjnej dot. Czesława Andrzejuka; 2912/1, Karty o symbolu EO-4-A/74, EO-4/73, Mkr-2, E-16 z kartoteki odtworzeniowej dot. Czesława Andrzejuka; Archiwum Instytutu Pamięci Narodowej w Lublinie (dalej: AIPN Lu), Wojewódzki Urząd Spraw Wewnętrznych (dalej: WUSW w Lublinie), 00226/1, Karta o symbolu Mkr-2 z kartoteki ogólnoinformacyjnej dot. Czesława Andrzejuka; AIPN Lu, Wojewódzki Urząd Spraw Wewnętrznych w Białej Podlaskiej (dalej: WUSW w Białej Podlaskiej), 00119/687, Teczka personalna ps. „Maciej” dot. Czesława Andrzejuka.

${ }^{31}$ Biogram gen. dyw. Teodora Kufla zob. Instrukcje pracy kontrwywiadowczej..., s. 23-25; B. Kapuściak, Misja wojskowa gen. dyw. Teodora Kufla w Berlinie Zachodnim w latach 1979-1981. Przyczynek do biografii szefa Wojskowej Stużby Wewnętrznej [w:] Attachés i przedstawiciele Misji Wojskowych w Wojsku Polskim II RP i Siłach Zbrojnych PRL, red. B. Kapuściak, 
do oddziaływania na przyszłych duchownych. Ponadto zastępca szefa WSW nakazywał rozdzielić i separować alumnów w jednostce wojskowej, by nie mieli ze sobą kontaktu; dążyć do pozyskania wśród alumnów jak największej liczby tajnych współpracowników oraz rozpracowywać operacyjnie metody oddziaływania miejscowych księży i seminariów na kleryków w wojsku ${ }^{32}$.

We wrześniu 1963 r. Wydział Administracyjny Komitetu Centralnego PZPR opracował „Wnioski w sprawie powołania alumnów”, w których sugerował powoływać do wojska alumnów seminariów z pierwszych trzech roczników na stałe pozbawionych przywilejów, jak np. Wyższych Seminariów Duchownych (WSD) w Kielcach i Przemyślu, z diecezji, „których ordynariusze wyróżniają się wrogą postawą wobec Państwa”, oraz w przypadkach, gdy któreś z seminariów odniesie się negatywnie do kontroli dokonywanych przez kuratorium oświatowe. Władze komunistyczne chciały też dokonać werbunku do wojska alumnów z seminariów zakonnych, które zajmują się „antypaństwową działalnością". Tłumaczono to wysokim stanem liczbowym słuchaczy tych seminariów oraz wynikami dotychczasowych kontroli kuratoriów oświaty. Władze komunistyczne proponowały powołać alumnów z WSD w Kielcach, Przemyślu, Poznaniu, Gnieźnie, Gorzowie, Wrocławiu i Sandomierzu oraz, ze względu na postawę ordynariuszy, również w Olsztynie, Warszawie i Tarnowie - w sumie 202 kleryków. Dodatkowo z seminariów zakonnych w liczbie 73 alumnów ze zgromadzenia salezjanów (Towarzystwo św. Franciszka Salezego, ze względu na nowoczesne metody docierania do młodzieży, szczególnie robotniczej), franciszkanów (Zakon Braci Mniejszych, ze względu na dużą liczbę zakonników i antykomunistyczne poglądy), werbistów (Zgromadzenie Słowa Bożego, ze względu na rozległe kontakty z zagranicą i „proniemieckie tendencje”), redemptorystów (Zgromadzenie Najświętszego Odkupiciela, ze względu na prowadzenie działalności misyjnej wśród marynarzy obcokrajowców w Gdyni i ścisłe kontakty z kardynałem Stefanem Wyszyńskim) i paulinów (ze względu na Jasną Górę i silne oddziaływanie na „masy wyznawców”, działalność Instytutu Wydawniczego oraz „negatywną postawę wobec komisji wizytacyjnej”) ${ }^{33}$.

Ostatecznie pod koniec 1963 r. wcielono do wojska 179 alumnów ${ }^{34}$. Przy tym szef GZP WP, gen. Wojciech Jaruzelski, uznał, że część z nich należy

Katowice-Warszawa, [w przygotowaniu]; https://katalog.bip.ipn.gov.pl/informacje/27068 (dostęp 15 IX 2020 r.).

32 AIPN, SWSW, 2386/31261, Pismo zastępcy szefa Wojskowej Służby Wewnętrznej, płk. Teodora Kufla nr BB-01124/10/63, [Warszawa] 3 II 1963 r., k. 166.

33 AIPN, MSW, 0639/231, t. 2, Wnioski w sprawie powołania alumnów wyższych seminariów duchownych do zasadniczej służby wojskowej w roku 1963, Warszawa wrzesień 1963 r., k. 3-11. Stamtąd też cytaty.

34 Gdzie indziej jest mowa o 154 alumnach rozproszonych po 69 jednostkach wojskowych. Zob. ibidem, Informacja [gen. Jana Czapli, zastępcy szefa GZP WP] o wynikach pracy 
skierować do tzw. dywizji pierwszorzutowych, co spowoduje znacznie skuteczniejsze oddziaływanie na nich. Według dokumentów GZP WP poszczególne seminaria duchowne miały dobrze przygotować nowo wcielonych alumnów do służby wojskowej. Byli oni posłuszni i dokładnie wykonywali rozkazy - rywalizowali nawet o odznakę "Wzorowego Żołnierza” i starali się o wystawianie im dobrych opinii po służbie, które przedkładali w seminariach ${ }^{35}$. Aktywizowali się społecznie, by móc przyciągnąć do siebie innych żołnierzy, nad którymi górowali intelektualnie i na których mogli oddziaływać. Starali się unikać prezentowania wrogiej postawy. Dodatkowo po ukończeniu służby wojskowej mieli oni rzekomo zagwarantowany skrócony czas nauki w seminariach, możliwość wyjazdu na studia teologiczne za granicę z odpowiednim stypendium. Natomiast po powrocie do seminarium mieli otrzymywać: „Zwiększoną kwotę tzw. kieszonkowego, zezwolenie na palenie papierosów, traktowani są przy tym jako ci, którzy przeszli próbę charakteru, trwałości swych przekonań i zdali ją z pomyślnym wynikiem”. Stąd gen. Jaruzelski optował za próbą przyuczania alumnów w wojsku, tak by po zakończeniu służby posiadali oni zawód, co sprzyjałoby podjęciu decyzji o rezygnacji ze studiów. Proponował także powoływanie do wojska tylko słuchaczy pierwszego, w ostateczności drugiego roku studiów, młode roczniki było bowiem łatwiej nakłonić do rezygnacji z drogi kapłaństwa. Miano także oferować alumnom przejście na studia cywilne z możliwością odroczenia wojska oraz szerzej współpracować z rodzinami alumnów poprzez listy i zapraszanie do jednostek, w których służyli ich synowie celem pokazania pozytywnego oblicza wojska. Podobnych pomysłów ukierunkowanych na wywarcie wpływu na alumnów i nakłonienie ich do porzucania studiów i drogi kapłaństwa było zresztą więcej ${ }^{36}$. Działania te nie do końca szły w sukurs organom WSW, które starały się z kolei jak największą liczbę alumnów zwerbować, „zabezpieczając” w ten sposób zarówno przyszłych księży, jak i pozostałych żołnierzy służby zasadniczej. Początkowo kontrwywiad wojskowy nie był skłonny przekazywać po zakończeniu służby wojskowej swoich tajnych współpracowników do terenowych jednostek SB. Werbunki

z żołnierzami-alumnami seminariów diecezjalnych i zakonnych zwolnionych do rezerwy jesienią br., [Warszawa] 29 XI 1965 r., k. 109.

35 Inaczej wspomina awanse jeden z byłych kleryków-żołnierzy: „Naszym hasłem było «wysłużyć» a nie «zasłużyć się» w takim wojsku. Awansowanie nas przez takich dowódców byłoby dla nas obelgą. Dowództwo nie dało za wygraną i podejmowało próby skłócenia nas także w tej materii". Cyt. za: T. Wawryszko, Klerycy w wojsku..., s. 33.

36 AIPN, MSW, 0639/231, t. 2, Notatka służbowa [szefa GZP WP, gen. Wojciecha Jaruzelskiego] o sytuacji wśród alumnów wyższych seminariów duchownych, odbywających zasadniczą służbę wojskową, [Warszawa] 12 XII 1963 r., k. 13-22. Stamtąd też cytat. By lepiej rozpracować środowisko alumnów, szef WSW obiecał przesyłać na bieżąco informacje o przebiegu ich służby do GZP WP. Zob. ibidem, Notatka z przebiegu konferencji odbytej w dniu 24 I 1964 r. w Głównym Zarządzie Politycznym WP, [Warszawa] 7 II 1964 r., k. 25v. 
kleryków były doraźne, a zadania im powierzane skupione na aktualnych potrzebach organów WSW, czyli na zabezpieczaniu jednostek i tzw. otoczenia wokół nich, nad czym ubolewały cywilne organy aparatu represji ${ }^{37}$.

Okres lat 1959-1964 kończy powoływanie alumnów do wojska tylko z niektórych seminariów diecezjalnych i zakonnych. Upowszechnienie służby wśród kleryków nastąpiło w roku 1965. Zakończył się też proces rozpraszania alumnów po poszczególnych jednostkach na rzecz grupowania ich w pododdziałach. Do 1964 r. klerycy-żołnierze służyli w 94 różnych jednostkach.

\section{II etap: lata 1964-1966}

Od października 1964 r. do października 1966 r. alumni byli zgrupowani w trzech kompaniach: w Opolu, Szczecinie i Gdańsku-Stogach. Akcja ta zbiegła się w czasie z przygotowaniami i obchodami Milenium Chrztu Polski organizowanymi przez Kościół katolicki w całej Polsce ${ }^{38}$.

Dla pionu politycznego wojska zgrupowanie alumnów w wyodrębnionych jednostkach miało być „nowym jakościowo etapem”. Władze seminaryjne dalej uświadamiały młodym studentom zagrożenia ideologiczne ze strony wojska i jednocześnie przygotowywały ich coraz lepiej na ewentualne odpowiedzi, uodparniając w ten sposób na pogadanki organizowane, w zwiększonej liczbie niż dotychczas, przez GZP WP. Dla odchodzących do wojska organizowane były w seminariach specjalne pożegnania, w których często uczestniczyli ordynariusze danych diecezji, a w przypadkach wspólnot zakonnych przełożeni

37 Ibidem, t. 1, Pismo zastępcy naczelnika Wydziału IV KWMO w Krakowie do naczelnika Wydziału I Departamentu IV MSW, Kraków 17 I 1966 r., k. 43. Tak jeden z byłych kleryków-żołnierzy wspomina próby skompromitowania go przez oficera kontrwywiadu: „Ściągnął [oficer WSW - przyp. B. K.] do jednostki żołnierza pochodzącego z Gubina. Janusz grywał z nim przed wojskiem w brydża. Tak zarządził, by Janusz był na jednej sali ze mną. Gdy przyszedł jako nowy na salę - nic nie podejrzewając, pomogłem mu przynieść łóżko, potraktowałem jako kolegę. Po pewnym czasie Janusz powiedział mi, że zna się z oficerem kontrwywiadu i że to on z powodu mnie ściągnął go do jednostki. Otrzymał zadanie i propozycję. Była bardzo konkretna. «Zaprzyjaźnij się z nim a potem zaprowadź go do burdelu i zostaw samego». Byłby to sukces bojowy kontrwywiadu, odkryć że klerykżołnierz był w burdelu. Janusz odmówił i mnie przestrzegał, że tego zadania może podjąć się ktoś inny”. Cyt. za: K. Dziubaczka, „A on do wojska był przynależniony” [w:] Mundur i sutanna..., s. 113-114.

38 Zob. na ten temat chociażby zbiór studiów i materiałów: Pół wieku Milenium. Religijne, polityczne i społeczne aspekty obchodów tysiąclecia Chrztu Polski (1956-1966/1967), red. B. Noszczak, Warszawa 2017. Opis działań WSW w trakcie obchodów milenium, zob. L. Kowalski, Krótsze ramię..., s. 253-257. Na temat wpływu Kościoła katolickiego na wojsko w związku z obchodami Chrztu Polski, zob. AIPN, SWSW, 2386/30713, Ppłk Henryk Kramek, „Wroga działalność kleru katolickiego w Polsce i oddziaływanie na wojsko”, praca egzaminacyjna, Wyższy Kurs Doskonalenia Oficerów WSW - Wojskowa Akademia Polityczna, Warszawa maj 1962 r., s. 37-42. 
generalni i prowincjalni. Miało to na celu podtrzymanie przyszłych księży na duchu i pokazanie im, że Kościół o nich na pewno nie zapomniał. Zachęcano ich zresztą do pisania listów, spotykania się z miejscowymi proboszczami przy jednostkach wojskowych, wzajemnego wspierania. Organa WSW były powiadamiane o treści listów dzięki perlustracji korespondencji kleryków dokonywanej przez $\mathrm{SB}^{39}$. Same zresztą dokonywały takowej w jednostkach wojskowych, w których służyli alumni ${ }^{40}$. Ku zgrozie GZP WP alumni często wynosili z jednostek polityczne konspekty, które przywozili do seminariów, a tam opracowywano na nie odpowiedzi dostarczane z kolei do macierzystych pododdziałów, gdzie rozpowszechniano je wśród innych żołnierzy. Wzmagało to także odwagę i radykalizowało postawy alumnów względem oficerów politycznych. Zmniejszyła się też liczba wystąpień z seminariów ${ }^{41}$. Łącznie w okresie 1959-1966 zrezygnowało ze studiów 120 alumnów, co miało stanowić $18 \%$ ogółu ${ }^{42}$.

Od 1964 r. zamiast rozpraszać kleryków po poszczególnych jednostkach uznano, że lepiej będzie sformować pododdziały, które w większości będą się składać z przyszłych księży. Alumnów drugiego rocznika, w liczbie 158 żołnierzy, pozostawiono rozproszonych po różnych jednostkach, natomiast kolejny powoływany jesienią planowano wcielić do służby w trzech pododdziałach: w baterii moździerzy 40 Pułku Zmechanizowanego 10 Dywizji Pancernej w Opolu (złożony z samych alumnów), w kompanii saperów 41 Pułku Zmechanizowanego 12 Dywizji Zmechanizowanej w Szczecinie (złożony w 2/3 z alumnów), w 25 Baterii Artylerii Stałej w Gdańsku-Stogach (złożony także w $2 / 3$ z alumnów). Reszta składu osobowego tych pododdziałów miała

39 AIPN, MSW, 0639/231, t. 1, Informacja z inwigilacji korespondencji b[yłych] alumnów Seminariów Duchownych, którzy pełnią obecnie służbę wojskową w jednostkach objętych pracą „W”, Koszalin 20 I 1964 r., k. 38-39.

40 A. Lesiński, Stużba wojskowa..., s. 43.

41 AIPN, MSW, 0639/231, t. 2, Informacja [Urzędu ds. Wyznań i GZP WP] o politycznych i organizacyjnych wynikach powołań alumnów WSD do odbywania zasadniczej służby wojskowej w latach 1959-1964, [Warszawa] 26 IX 1964 r., k. 39-42.

${ }^{42}$ Ibidem, Informacja [płk. Leona Morawskiego, szefa Oddziału I Zarządu I GZP WP] o przebiegu zwolnienia do rezerwy i powołaniu do zasadniczej służby wojskowej alumnów seminariów diecezjalnych i zakonnych, [Warszawa] 4 XI 1966 r., k. 152. Gdzie indziej podawana jest liczba 123 alumnów na 688 odbywających służbę wojskową w okresie 1959-1966, co stanowi 19\%. Zob. ibidem, Notatka [Urzędu ds. Wyznań] o społeczno-politycznych postawach alumnów i księży którzy odbyli służbę wojskową, Warszawa 30 VIII 1967 r., k. 188. Zupełnie inne dane posiadał Departament IV MSW. Łączna liczba alumnów w wojsku w latach 1959-1966 miała wynosić 744 osoby, z czego zrezygnowało z seminarium 162 alumnów. Zob. ibidem, Uwagi robocze do notatki Urzędu ds. Wyznań w sprawie polityczno-społecznych postaw księży i alumnów, którzy odbyli służbę wojskową, Warszawa 7 IX 1967 r., k. 198. Jeszcze inne wyliczenia zrobił Setlak, opierając je na materiałach Sekretariatu Episkopatu Polski. Zob. A. Setlak, Wojskowa stużba..., s. 329. 
Tabela 1. Skala rezygnacji z nauki w WSD alumnów, którzy odbyli służbę wojskową w latach 1959-1964, opracowana przez Wydział Administracyjny KC PZPR

\begin{tabular}{|l|c|c|c|}
\hline $\begin{array}{c}\text { Rok } \\
\text { wcielenia }\end{array}$ & $\begin{array}{c}\text { Liczba przeszkolonych } \\
\text { i zwolnionych alumnów } \\
\text { do rezerwy }\end{array}$ & $\begin{array}{c}\text { Liczba rezygnujących } \\
\text { z kontynuowania nauki } \\
\text { w WSD }\end{array}$ & Procentowo \\
\hline 1959 & 63 & 16 & $26 \%$ \\
\hline 1960 & 73 & 32 & $44 \%$ \\
\hline 1961 & 86 & 21 & $24 \%$ \\
\hline 1962 & 151 & 13 & $9 \%$ \\
\hline 1963 & 154 & 12 & $8 \%$ \\
\hline 1964 & 161 & 29 & $18 \%$ \\
\hline
\end{tabular}

Źródło: AIPN, MSW, 0639/231, t. 2, Ocena postaw księży i alumnów WSD, którzy po ukończeniu służby wojskowej pracują w placówkach duszpasterskich lub studiują nadal w seminariach, [Wydział Administracyjny KC PZPR], Warszawa wrzesień 1967 r., k. 219

składać się z tzw. „aktywistów”, czyli członków PZPR lub komunistycznych organizacji młodzieżowych ${ }^{43}$. Kadra i szeregowi włączeni do pododdziałów złożonych z alumnów musieli być odpowiednio wyselekcjonowani, ze „skrystalizowanym światopoglądem materialistycznym”. Na początku stycznia 1965 r. planowano około 10\% stanu osobowego alumnów skierować do szkół podoficerskich i przeszkolić na dowódców drużyn. Dodatkowo w ich składzie wytypowani mieli być oczywiście tajni współpracownicy ${ }^{44}$. Miał być to swego rodzaju eksperyment pozwalający skłócać kleryków z różnych seminariów, szczególnie antagonizmy miały występować między studentami seminariów diecezjalnych i zakonnych ${ }^{45}$.

Po przybyciu alumnów do jednostek oficerowie WSW musieli sporządzić charakterystyki każdego z nich, wytypować odpowiednią liczbę osób do werbunku i pozyskać je, tak by można było „zabezpieczyć operacyjnie”

43 AIPN, SWSW, 2386/19700, Pismo szefa Wojskowej Służby Wewnętrznej nr BB-008401/10/64, [Warszawa] 1 XII 1964 r., k. 158-159. Początkowo brano pod uwagę utworzenie poza etatem kompanii zmechanizowanej 75 Pułku Zmechanizowanego z 15 Dywizji Zmechanizowanej w Bartoszycach, ostatecznie jednak zostali wcieleni do baterii artylerii nadbrzeżnej Marynarki Wojennej w Gdańsku; zob. AIPN, MSW, 0639/231, t. 2, Notatka służbowa [GZP WP] zawierająca propozycje wprowadzenia w życie nowych zasad wcielenia i przeszkalania w wojsku alumnów wyższych seminariów duchownych i zakonnych, [Warszawa] 17 XI 1964 r., k. 56-57; Informacja nr 3/65 [gen. Jana Czapli, zastępcy szefa GZP WP] o przebiegu służby wojskowej alumnów WSD zgrupowanych w wyodrębnionych pododdziałach w Gdańsku, Opolu i Szczecinie, [Warszawa] 17 IX 1965, k. 81-89. Zob. także: S. Bobulski, Klerycy - marynarze...

44 AIPN, SWSW, 2386/19700, Pismo nr BB-008401/10/64 szefa Wojskowej Służby Wewnętrznej, [Warszawa] 1 XII 1964 r., k. 158-160.

45 AIPN, MSW, 0639/231, t. 2, Informacja nr 3/65 [gen. Jana Czapli, zastępcy szefa GZP WP] o przebiegu służby wojskowej alumnów WSD zgrupowanych w wyodrębnionych pododdziałach w Gdańsku, Opolu i Szczecinie, [Warszawa] 17 IX 1965 r., k. 84. 
sformowane z alumnów pododdziały. Szczególny nacisk kładziono na rozpoznanie oddziaływania na alumnów seminariów duchownych i księży ${ }^{46}$. Już wcześniej Szefostwo WSW ponaglało Departament IV MSW (pion antykościelny SB w latach $1962-1989^{47}$ ) odpowiedzialny teraz za rozpracowywanie Kościołów i mniejszości wyznaniowych, aby przesłał informację "o aktualnych kierunkach pracy seminariów duchowych i zakonnych oraz kleru katolickiego" w zakresie przygotowania alumnów do służby wojskowej, utrzymywania z nimi kontaktów i wspierania ich podczas odbywania służby wojskowej oraz wykorzystywania ich w wojsku do „klerykalnego oddziaływania" na pozostałych żołnierzy ${ }^{48}$. Takie prośby były także przesyłane w kolejnym roku ${ }^{49}$.

W 1965 r. planowano utrudnić wnoszenie przez alumnów do jednostek wojskowych literatury o treści religijnej. Na zebraniu, które odbyło się 19 lutego 1965 r. w Generalnej Prokuraturze, na którym obecni byli zastępca Prokuratora Generalnego, Naczelny Prokurator Wojska Polskiego, przedstawiciel GZP WP, przedstawiciel Urzędu ds. Wyznań oraz przedstawiciel Szefostwa WSW, uznano, że każdy, kto posiada broszurę albo książkę bez debitu, będzie pociągany do odpowiedzialności karnej. Chodziło oczywiście głównie o broszury dotyczące sytuacji politycznej i polemiki Kościoła katolickiego z aparatem politycznym, ale przede wszystkim o skrypty, które służyły alumnom do przygotowania się do złożenia egzaminów. Co ciekawe, lepszą orientację w tym zagadnieniu posiadali oficerowie polityczni niż organa WSW. Rozpatrywanie wniosków miało mieć miejsce w stosunku do: „1. Organizatorów zbierania i rozpowszechniania nielegalnej literatury.

2. Żołnierzy szczególnie wrogo ustosunkowanych do przemian zachodzących w Polsce i prowadzących wrogą agitację co do polityki porozumień państwa z kościołem.

46 AIPN, SWSW, 2386/19700, Pismo szefa Wojskowej Służby Wewnętrznej nr BB-008401/10/64, [Warszawa] 1 XII 1964 r., k. 158-160.

47 Szerzej zob. F. Musiał, Departament IV MSW..., s. 41-168.

48 AIPN, MSW, 0639/231, t. 2, Pismo zastępcy szefa Zarządu I Szefostwa WSW, płk. Jerzego Markuszewskiego, do dyrektora Departamentu IV MSW nr BB-08220/10/64, [Warszawa] 20 XI 1964 r., k. 54. Zob. także ponaglenie tej prośby: ibidem, Pismo zastępcy szefa Wojskowej Służby Wewnętrznej, płk. Jerzego Mrówczyńskiego, do dyrektora Departamentu IV MSW nr BB-01193/10/65, [Warszawa] 2 III 1965 r., k. 55. Biogram płk. Jerzego Markuszewskiego zob. B. Kapuściak, „Historia oceni kto miat rację”. Zarząd Wojskowej Stużby Wewnętrznej 2. Armii i jego rola w zabezpieczeniu inwazji na Czechosłowację [w:] Okupanci. Interwencja wojsk Układu Warszawskiego w Czechosłowacji w 1968 r., red. S. Ligarski, Szczecin-Warszawa [w przygotowaniu]; https://katalog.bip.ipn.gov.pl/informacje/36395 (dostęp 15 IX 2020 r.).

49 AIPN, MSW, 0639/231, t. 2, Pismo zastępcy szefa Zarządu I Szefostwa WSW, płk. Jerzego Markuszewskiego, do dyrektora Departamentu IV MSW nr BB-02167/10/66, [Warszawa] 6 X 1966 r., k. 138. 
3. Skompromitowanych lub posiadających skompromitowane rodziny (represjonowani przez nasze władze, nacjonaliści notowani przez organa bezpieczeństwa i inne)" 50 .

Wachlarz „przestępstw” był więc dość szeroki i aby zebrać odpowiednie materiały, zastępca szefa WSW, płk Jerzy Mrówczyński, polecił:

„1. Na terenie kompanii żołnierzy (alumnów) pozyskać odpowiednią ilość tajnych współpracowników, dla dokładnego rozpoznania tego środowiska.

2. Ustalać wszelkiego rodzaju organizatorów, prowokatorów i aktywistów, którzy de[z]organizują pracę wychowawczą w tych kompaniach, gromadzą wokół siebie żołnierzy, określają kierunki przeciwdziałania naszej pracy.

3. Rozpoznawać żołnierzy wywożących, w czasie wyjazdu do seminariów lub wynoszących do miejscowego kleru materiałów poufnych i jawnych dotyczących szkolenia politycznego, które stanowią podstawę do opracowywania materiałów i kontrargumentów przez seminaria dla alumnów.

4. Prowadzić systematycznie sprawdzania tych żołnierzy i naświetlenie ich przez tajnych współpracowników i kontakty operacyjne, w celu ustalania kompromitujących materiałów.

5. Występować z umotywowanymi wnioskami na areszt organizatorów rozpowszechniania wrogiej literatury, listów, po uprzednim zebraniu opinii dowództwa i aparatu politycznego.

6. Systematycznie informować Szefostwo WSW o pracy wśród alumnów, przekładać bardziej interesującą korespondencję i literaturę, szerzej korzystać z opinii Szefostwa w sprawie rozpracowań i postępowania w stosunku do alumnów" ${ }^{51}$.

Jeszcze w 1964 r. w Szefostwie WSW pracowano nad zarządzeniem dotyczącym współpracy między Departamentem IV MSW a WSW w sprawie pracy operacyjnej wśród alumnów odbywających zasadniczą służbę wojskową ${ }^{52}$. W projekcie zarządzenia wśród głównych kierunków pracy operacyjnej w środowisku alumnów wymieniono:

„a. dążenie do odciągnięcia jak największej ilości kleryków od nauki w seminariach,

50 Cyt. AIPN, SWSW, 2386/19700, Pismo nr BB-01124/10/65 zastępcy szefa Wojskowej Służby Wewnętrznej płk. Jerzego Mrówczyńskiego, [Warszawa] 26 II 1965 r., k. 187. Przebieg służby płk. Jerzego Mrówczyńskiego (ur. 4 II 1923 r. w Żyrardowie) zob. https://katalog.bip. ipn.gov.pl/informacje/69238 (dostęp 15 IX 2020 r.).

${ }^{51}$ Cyt. za: AIPN, SWSW, 2386/19700, Pismo nr BB-01124/10/65 zastępcy szefa Wojskowej Służby Wewnętrznej płk. Jerzego Mrówczyńskiego, [Warszawa] 26 II 1965 r., k. 187-188.

${ }^{52}$ Ibidem, Zarządzenie dyrektora Departamentu IV MSW i zastępcy szefa WSW w sprawie pracy operacyjnej w związku z odbywaniem służby wojskowej przez kleryków - projekt, Warszawa styczeń 1965 r., k. 190-193. 
b. przygotowanie wśród nich odpowiedniej ilości tajnych współpracowników dla potrzeb pracy operacyjnej w seminarium i wśród kleru,

c. rozpoznawanie zapatrywań, poglądów społeczno-politycznych, cech charakteru i kontaktów kleryków,

d. ujawnienie powiązań kleryków z otoczeniem, form i metod oddziaływania na nich przez miejscowy kler, kierownictwo seminarium i hierarchię kościelną" 53 .

W celu realizacji tych kierunków oddziały i wydziały WSW miały za zadanie (we współpracy z terenowymi Wydziałami IV Komend Wojewódzkich Milicji Obywatelskiej - KWMO) rozpoznawanie nastrojów, wypowiedzi, nawyków, religijności (tzw. stopnia sfanatyzowania) poszczególnych alumnów; ustalenia powiązań z miejscowymi księżmi oraz kierownictwem seminariów i ewentualne przekazywanie im informacji, jak i ujawnienie zadań przekazywanych z seminariów lub poprzez biskupów (przy tym oficerowie WSW mieli utrudniać te kontakty); przeciwdziałanie w zbieraniu informacji przez alumnów o sytuacji w wojsku; zbieranie na kleryków-żołnierzy materiałów kompromitujących; pozyskiwanie wśród nich tajnych współpracowników i ewentualne przekazywanie ich na kontakt SB (ścisłe wiązanie ich z organami WSW i SB, tak by uniemożliwić im po wyjściu z wojska odmowę współpracy); poprzez środki operacyjne skłanianie alumnów do prowadzenia świeckiego życia.

Wydziały IV KWMO zobowiązano do przekazania tajnych współpracowników spośród kleryków powołanych do wojska oraz przesyłania do danych Wydziałów IV KWMO na terenie, gdzie alumni odbywali służbę wojskową, teczek ewidencji operacyjnych na księdza (TEOK) oraz innych materiałów operacyjnych na danych seminarzystów i udostępnienie ich oficerom WSW do wglądu. W zamian za to oddziały/wydziały WSW po zakończeniu przez alumnów zasadniczej służby wojskowej miały przesyłać poprzez Wydział I Oddziału IV Szefostwa WSW (ewidencja i archiwum WSW) do terenowych Wydziałów IV KWMO wszelkie materiały operacyjne zebrane na nich w trakcie odbywania tejże służby.

Ciekawa jest notatka oficera Szefostwa WSW ${ }^{54}$ ze spotkania z zastępcą

53 Cyt. za: ibidem, k. 190.

54 Podpis oficera WSW pod notatką jest niewyraźny, prawdopodobnie podpisał ją mjr Stanisław Dobrzański, w tym czasie starszy pomocnik szefa Wydziału I Oddziału III Zarządu I Szefostwa WSW (2 VII 1964 r. - 2 IX 1965 r.), który później był odpowiedzialny za kontakty z Departamentem IV MSW w sprawie alumnów (zob. AIPN, MSW, 0639/231, t. 2, Pismo nr BB-0623/10/70 w sprawie upoważnienia ppłk. Stanisława Dobrzańskiego wystawionego przez szefa Oddziału IV Szefostwa WSW, płk. Tadeusza Nowaka, [Warszawa] 6 IV 1970 r., k. 294). Oddział III Zarządu I zajmował się koordynacją i nadzorem pracy kontrwywiadowczej prowadzonej przez inne jednostki organów WSW, prowadził też poważniejsze rozpracowania agenturalne. Analizował także formy i metody wrogiej działalności wobec Sił Zbrojnych PRL, w tym także Kościoła katolickiego. Od 1961 r. podzielony był na dwa wydziały. Z trzech 
dyrektora Departamentu IV MSW płk. Zenonem Gorońskim ${ }^{55}$ dotyczącego współpracy organów aparatu represji. W notatce tej, datowanej na 22 kwietnia 1965 r., oficer WSW referował:

„W rozmowie płk Goroński zakomunikował mi, że po konsultacji z Dyrektorem Departamentu IV i Ministrem Spraw Wewnętrznych, Ministerstwo Spraw Wewnętrznych nie zgodzi się na podpisanie tego zarządzenia ani też na wydanie żadnego innego wspólnego dokumentu w sprawie kleryków, chociażby - jak się wyraził płk Goroński - dokument ten miał zawierać choćby kilka zdań, gdyż taki dokument nie jest potrzebny. Nie chodzi o to - jak stwierdził płk Goroński - że MSW nie chce z nami współpracować na tym odcinku, ale o to, by to, co robimy wśród kleru i kleryków, nie miało odbicia $\mathrm{w}$ dokumentach normatywnych.

Płk Goroński zaznaczył przy tym, że wszystko to, co zawiera przedstawiony MSW projekt wspólnego zarządzenia, jest jak najbardziej słuszne i godne aprobaty i powinno być realizowane w praktyce, ale jednocześnie - ich zdaniem - nie musi mieć formy pisemnych wytycznych czy dokumentu normatywnego. Płk Goroński wyraził się dosłownie «robimy to wszystko skrupulatnie, ale nigdzie nie piszemy o tym»" 56 .

opracowań Wyższego Kursu Doskonalenia Oficerów WSW dotyczących wrogich elementów dwa odnoszą się do Kościoła katolickiego (zob. AIPN, SWSW, 2386/19700, Wykaz tematów opracowanych przez słuchaczy WKDO WSW w latach 1961-1964, [Warszawa 1964 r.], k. 151). Stanisław Dobrzański (ur. 1 XI 1927 r. w Zręcinie, pow. krosnowski - pow. krośnieński) służbę w „odrodzonym” WP rozpoczął 15 IX 1948 r., kiedy został skierowany do Oficerskiej Szkoły Inżynieryjno-Saperskiej we Wrocławiu, a stamtąd do Ośrodka Szkolenia Informacji. W organach GZI służył w latach 1951-1957, czyli do czasu przeformowania w Wojskową Służbę Wewnętrzną. Od początku służył w Szefostwie WSW, najpierw w samodzielnym Wydziale VI, następnie w Oddziale IV Zarządu I, a po ukończeniu Kursu doskonalenia oficerów w Ośrodku Szkolenia WSW wrócił do Wydziału VI. Od 16 IV 1960 r. starszy pomocnik szefa Wydziału II Oddziału Kadr i Szkolenia, później służył w Wydziale I Oddziału III Zarządu I Szefostwa WSW (6 XII 1961 r. - 2 IX 1965 r.), następnie został mianowany starszym pomocnikiem szefa Oddziału I Zarządu I Szefostwa WSW w okresie 2 IX 1965 r. - 9 VI 1967 r. Dalszą służbę pełnił w Oddziale I Zarządu II i Oddziale I Zarządu III Szefostwa, którą zakończył ostatecznie 8 X 1979 r. Zob. AIPN, Zbiór akt personalnych żołnierzy pełniących służbę w cywilnych i wojskowych organach bezpieczeństwa państwa (w tym żołnierzy represjonowanych z motywów politycznych) oraz pracowników cywilnych wojska, 2300/1360, Teczka Akt Personalnych Dobrzańskiego Stanisława, s. Alojzego.

55 Przebieg służby płk. Zenona Gorońskiego (ur. 21 VI 1924 r. w Poznaniu) zob. A. Dziurok, "Ignorować Wyszyńskiego. My go przeżyjemy i zwyciężymy”. Notatka $z$ wykładu wicedyrektora Departamentu IV MSW płk. Zenona Gorońskiego z kwietnia 1969 r., „Aparat Represji w Polsce Ludowej 1944-1989" 2006, nr 2 (4), s. 255-256; http://katalog.bip.ipn.gov. $\mathrm{pl} /$ informacje/117792 (dostęp 15 IX 2020 r.).

56 Cyt. za: AIPN, SWSW, 2386/19700, Notatka dot. współpracy WSW i MSW w sprawie kleryków, [Warszawa] 22 IV 1965 r., k. 195-196. W notatce błędnie wpisano nazwisko: 
Pułkownik Goroński poinformował oficera WSW, że wszelkie wytyczne MSW są przekazywane ustnie na odprawach. Radził, by organa WSW postępowały w podobny sposób, nie tworząc dokumentów normatywnych ${ }^{57}$.

$\mathrm{O}$ tym, że nie posłuchano rad doświadczonych funkcjonariuszy z cywilnego aparatu represji, świadczy chociażby pismo szefa WSW nr A-0041 z 2 lipca 1965 r. ${ }^{58}$, z którego wynika, że podczas przeprowadzonej kontroli zauważono brak postępów w pracy operacyjnej z alumnami. Kontrwywiad wojskowy nie tylko nie zdołał wykazać kontaktów i przekazywanych informacji między seminariami a alumnami, ale także nie był w stanie związać młodych kleryków ze sobą czy dokonywać wśród nich werbunku. $Z$ dokumentu można wywnioskować, że Kościół katolicki próbował bronić się i ochraniać swoich alumnów przed próbami werbunku. Co więcej, sami klerycy unikali kontaktów z żołnierzami „aktywistami”, traktując ich jako wtyczki oficerów politycznych ${ }^{59}$.

Według wytycznych z 1965 r. ówczesnego szefa WSW, płk. Teodora Kufla, w sprawie postępowania wobec alumnów odbywających służbę wojskową, pobór przyszłych księży nie miał na celu odciągnięcia ich od kontynuowania nauki w seminariach, ale „pokazanie klerykom rzeczywistego obrazu Polski ludowej, jej polityki[,] osiągnięć i zadań - często niewłaściwie naświetlanych w seminariach - i przyczynienia się do przyjęcia przez nich w przyszłej pracy duszpasterskiej pozycji księży lojalnych, postępowych, patriotów"60. Dostrzeżono wobec tego, że represje i szykany nie zniechęcają do opuszczenia seminariów, ale raczej do służby wojskowej. Główny Zarząd Polityczny WP wraz z WSW zmieniły wobec tego taktykę ${ }^{61}$. Postanowiono

Garoński.

57 Ibidem, k. 196.

58 Ibidem, 2386/18195, Pismo szefa WSW nr A-0041 [wytyczne w sprawie postępowania wobec alumnów odbywających służbę wojskową], [Warszawa] 2 VII 1965 r., k. 89-95. Zob. także projekt tego pisma ibidem, 2386/19700, k. 201-208. Przedruk dokumentu zob. A. Marcinkiewicz-Kaczmarczyk, Wojskowa Stużba Wewnętrzna. Organizacja i zakres zadań [w:] Archiwalia komunistycznego aparatu represji - zagadnienia źródłoznawcze, pod red. F. Musiała, Kraków 2012, s. 242-247.

59 AIPN, MSW, 0639/231, t. 2, Informacja nr 3/65 [gen. Jana Czapli, zastępcy szefa GZP WP] o przebiegu służby wojskowej alumnów WSD zgrupowanych w wyodrębnionych pododdziałach w Gdańsku, Opolu i Szczecinie, [Warszawa] 17 IX 1965 r., k. 84.

60 Cyt. za: A. Marcinkiewicz-Kaczmarczyk, Wojskowa Stużba Wewnętrzna..., s. 242.

${ }^{61}$ Niestety, czasami sami księża w niefortunny sposób postępowali z żołnierzami-klerykami. Według informacji zdobytych przez GZP WP jeden z alumnów z 19 Dywizjonu Artylerii Przeciwlotniczej w Zgorzelcu chciał opuścić seminarium i związał się z dziewczyną, z którą planował wziąć ślub po skończeniu służby wojskowej. Za namową kolegi, który nakłaniał go do powrotu do stanu duchownego, udali się na plebanię w pobliżu jednostki, gdzie proboszcz miał rzekomo odprawiać nad nim egzorcyzmy, grożąc, że nie uzyska on 
zachęcać kleryków do wojska, jednocześnie próbując zniechęcać do Kościoła katolickiego, a przede wszystkim werbować agentów nie tylko na potrzeby „ochrony” jednostek w czasie ich służby. Od teraz głównym założeniem było przekazywanie agentów na potrzeby organów cywilnych, bo to one były odpowiednio przygotowane do walki z Kościołem katolickim. Planów tych nigdy nie zrealizowano na większą skalę, a większość alumnów, którzy zgodzili się na jakikolwiek rodzaj współpracy, było traktowanych z reguły jako kontakty operacyjne (później osoby zaufane). Dopóki klerycy byli rozproszeni po jednostkach wojskowych, praca agenturalna opierała się na żołnierzach świeckich. Tu jednak także pojawiał się problem, bo „poziom intelektualny alumnów jest wyższy od przeciętnych żołnierzy i niejednokrotnie naszych tajnych współpracowników, w związku z tym dotarcie i rozpoznanie ich jest w znacznym stopniu utrudnione"62. O oczytaniu i intelektualnej wyższości alumnów nad pozostałymi żołnierzami wspominał także szef GZP WP, gen. Jaruzelski ${ }^{63}$.

Żołnierze-klerycy sprawiali duży problem kontrwywiadowi wojskowemu. Organom tym brakowało doświadczenia w pracy z nimi. Specyfika armii jako instytucji oraz metody pracy operacyjnej służb w środowisku wojskowym powodowały łatwość werbunku zarówno wśród osób z otoczenia wojskowego, jak i cywilnego. Jednak w przypadku alumnów oficerowie mogli natrafić na opór i radykalizm młodych ludzi, na sprzeciw zarówno wobec służby wojskowej, jak i wobec oficerów kontrwywiadu wojskowego, traktowane w obu przypadkach jako rodzaj represji i prób przełamania ich światopoglądu. W związku z tym Szefostwo WSW zalecało, by pracę wobec alumnów prowadzono aktywniej niż dotychczas, ale w sposób „przemyślany, ostrożny i kulturalny”, z należytą „,inicjatywą i pomysłowością kontrwywiadowczą [sic!]”, której dotychczas brakowało.

$\mathrm{W}$ dokumencie tym znalazły się sformułowania wzięte z projektu zarządzenia dyrektora Departamentu IV MSW, płk. Stanisława Morawskiego, i zastępcy szefa WSW, płk. Jerzego Mrówczyńskiego w sprawie pracy operacyjnej w związku z odbywaniem służby wojskowej przez kleryków, o którym pisałem wyżej.

ślubu z wybraną kobietą i jego małżeństwo będzie potępione. Wstrząśnięty żołnierz-alumn po powrocie do jednostki miał targnąć się na swoje życie, wypijając butelkę płynu „Tri”. Zob. AIPN, MSW, 0639/231, t. 2, Informacja [gen. Jana Czapli, zastępcy szefa GZP WP] o wynikach pracy z żołnierzami-alumnami seminariów diecezjalnych i zakonnych zwolnionych do rezerwy jesienią br., [Warszawa] 29 XI 1965 r., k. 113.

62 Cyt. AIPN, SWSW, 2386/30839, Ppłk Adolf Sieradzki, „Praca kontrwywiadowcza wśród alumnów powołanych do wojska, Oddział Kadr i Szkolenia Szefostwa WSW", Warszawa styczeń 1964 r., s. 12-13.

${ }^{63}$ AIPN, MSW, 0639/231, t. 2, Notatka służbowa szefa GZP, gen. Wojciecha Jaruzelskiego, o sytuacji wśród alumnów wyższych seminariów duchownych, odbywających zasadniczą służbę wojskową, [Warszawa] 12 XII 1963 r., k. 15. 
Po jesiennym naborze 1965 r. planowano powołać kolejne trzy pododdziały złożone $\mathrm{z}$ alumnów seminariów duchownych i zakonnych (rocznik 1946) w liczbie ok. 220 osób: w 1 Pułku Pontonowym w Brzegu, 75 Pułku Zmechanizowanym (pz) w Bartoszycach i 32 pz w Kołobrzegu. Tym razem Szefostwo WSW planowało włączyć do każdego pododdziału po dziesięciu poborowych - aktywistów młodzieżowych o „zdecydowanie materialistycznym światopoglądzie”, wśród których znajdować się mieli tajni współpracownicy i kontakty operacyjne Służby Bezpieczeństwa bądź Milicji Obywatelskiej ${ }^{64}$.

W dalszym okresie włączano do pododdziałów 20-30\% żołnierzy „aktywistów". Dodatkowo przeznaczono etat w każdym batalionie złożonym $\mathrm{z}$ alumnów dla oficera WSW ${ }^{65}$. Przy dobieraniu kadry dowódczej dla poszczególnych pododdziałów złożonych z kleryków porozumiewano się z Zarządami Politycznymi i Oddziałami Kadr Okręgów Wojkkowych, kierując się „wysokimi walorami moralno-politycznymi”. Wojskowa Służba Wewnętrzna czuwała przy tym, aby odpowiednią liczbę tajnych współpracowników i kontaktów operacyjnych włączono do pododdziałów.

W październiku 1965 r. opuściło koszary 140 alumnów rozproszonych po różnych jednostkach. Wraz z nowym naborem w wojsku pełniło służbę ok. 370 alumnów zgrupowanych w sześciu pododdziałach. W następnym roku trzy pododdziały w Opolu, Szczecinie i Gdańsku-Stogach zostały rozformowane. Odtąd alumni służyli tylko w szkolnych batalionach ratownictwa terenowego ${ }^{66}$.

64 AIPN, SWSW, 2386/19700, Pismo zastępcy szefa zarządu Wojskowej Służby Wewnętrznej, płk. Jerzego Mrówczyńskiego, nr BB-03488/10/65, [Warszawa] 27 VII 1965 r., k. 211; MSW, 0639/231, t. 2, Informacja nr 4/65 zastępcy szefa GZP, gen. Jana Czapli, o przebiegu ostatniego wcielenia alumnów do jednostek w Brzegu, Bartoszycach i Kołobrzegu, [Warszawa] 19 XI 1965 r., k. 102-107. Kompanię alumnów z Bartoszyc i Kołobrzegu przeniesiono do Szczecina-Podjuch i utworzono dwukompanijny Szkolny Batalion Ratownictwa Terenowego. Następnie w Brzegu i Bartoszycach zaczęto formować nowe kompanie alumnów wraz z „aktywem” żołnierskim. Zob. ibidem, Informacja [płk. Leona Morawskiego, szefa Oddziału I Zarządu I GZP WP] o przebiegu zwolnienia do rezerwy i powołaniu do zasadniczej służby wojskowej alumnów seminariów diecezjalnych i zakonnych, [Warszawa] 4 XI 1966 r., k. 152-153.

65 AIPN, SWSW, 2386/19701, Pismo zastępcy szefa Wojskowej Służby Wewnętrznej, płk. Jerzego Mrówczyńskiego, nr BB-002040/10/66, [Warszawa] 19 IX 1966 r., k. 128-129.

${ }_{66}$ AIPN, MSW, 0639/231, t. 2, Informacja nr 3/65 [gen. Jana Czapli, zastępcy szefa GZP WP] o przebiegu służby wojskowej alumnów WSD zgrupowanych w wyodrębnionych pododdziałach w Gdańsku, Opolu i Szczecinie, [Warszawa] 17 IX 1965 r., k. 88-89. 


\section{Etap III: lata 1966-1980}

W 1965 r. utworzono ostatecznie trzy szkolne bataliony ratownictwa terenowego (SBRT) w Bartoszycach (JW 4413) ${ }^{67}$, Szczecinie-Podjuchach (JW 4422, rozformowany w 1973 r. $)^{68}$ i Brzegu (JW 4446, rozformowany w 1979 r.) do których kierowano alumnów ${ }^{69}$. Oprócz alumnów kierowano także i do tych jednostek tzw. aktyw partyjny, który zgodnie z zaleceniami szefa GZP WP, gen. Jaruzelskiego, był zobowiązany do rozpoznania środowiska żołnierzy-kleryków. Nadal charakter wcieleń, pomimo większej liczby powołań alumnów do wojska (w latach 1966-1969 w liczbie przekraczającej nawet 200 osób), miał charakter represyjny i zależał od postawy miejscowego ordynariusza ${ }^{70}$. W 1967 r. uchwalono nową ustawę o powszechnym obowiązku obrony PRL, co spowodowało oficjalne objęcie obowiązkiem powołania do służby wojskowej alumnów ze wszystkich seminariów ${ }^{71}$.

Organa WSW zaczęły także przyglądać się komisjom poborowym, które w dość łatwy sposób odraczały klerykom służbę. W samym $1966 \mathrm{r}$. na 1012 alumnów, którzy stawili się na komisjach lekarskich, tylko 563 zakwalifikowano jako zdolnych, 245 za zdolnych z ograniczeniami, a 204 uznano za niezdolnych w ogóle do służby wojskowej. Organa kontrwywiadu wojskowego przyjrzały się decyzjom Wojskowych Komisji Rekrutacyjnych i doszły do wniosku, że w niektórych miejscowościach mocno zawyżona jest liczba alumnów niezdolnych do służby w wyniku decyzji poszczególnych

${ }^{67}$ A. Czwołek, Stużba wojskowa..., s. 104-130.

68 T. Fitych, Stużba wojskowa..., s. 123.

69 L. Kowalski, Krótsze ramię..., s. 233. Rozkaz o rozformowaniu batalionu w Brzegu rzeczywiście został wprowadzony w życie w 1979 r., ale rozformowanie trwało do lutego 1980 r. Zob. P. Piotrowski, Stużba kleryków..., s. 167. Do Brzegu miało trafić 95 alumnów (trzech się nie stawiło), do Kołobrzegu 60 alumnów (także trzech się nie stawiło), do Bartoszyc 57 alumnów. Zob. AIPN, MSW, 0639/231, t. 2, Informacja nr 4/65 [gen. Jana Czapli, zastępcy szefa GZP WP] o przebiegu ostatniego wcielenia alumnów do jednostek w Brzegu, Bartoszycach i Kołobrzegu, [Warszawa] 19 XI 1965 r., k. 102; Ocena [GZP WP] pracy polityczno-wychowawczej prowadzonej z alumnami w Szkolnych Batalionach Ratownictwa Terenowego, [Warszawa] 4 XII 1968 r., k. 267-268. W następnych latach wcielano do wojska alumnów w liczbie: 1968 r. - 220, 1969 r. - 270, 1970 r. - 126, 1971 r. - 73, 1972 r. - 94, 1973 r. - 167, 1974 r. - 120, 1975 r. - 98. Zob. ibidem, Tezy dot. służby wojskowej alumnów WSD, Warszawa 28 XI 1975 r., k. 378. Inne dane podaje Setlak. Zestawienia te sporządził na podstawie informacji w aktach Sekretariatu Episkopatu Polski znajdujących się w Archiwum Episkopatu Polski. Zob. A. Setlak, Stużba wojskowa..., s. 25, 28-29.

70 AIPN, MSW, 0639/231, t. 2, Propozycje dot. poboru do wojska kleryków z Wyższych Seminariów Duchownych, Warszawa 17 IX 1968 r., k. 240.

${ }^{71}$ Ustawa z dn. 21 XI 1967 r. o powszechnym obowiązku obrony Polskiej Rzeczypospolitej Ludowej, (Dz.U. 1967, nr 44, poz. 220); AIPN, MSW, 0639/231, t. 2, Tezy dot. służby wojskowej alumnów WSD, Warszawa 28 XI 1975 r., k. 377. 
lekarzy. Lekarze ci, według ustaleń WSW, byli „klerykałami lub utrzymujący kontakt z klerem". Okazało się jednak, że ok. 70\% alumnów otrzymujących odroczenia, było kierowanych do lekarzy specjalistów, którzy w większości decyzje takie popierali, stąd ostatecznie WSW nie była w stanie udowodnić, że lekarze w komisjach celowo odraczali służbę klerykom. Pomimo nieznalezienia żadnych podstaw do udowodnienia działań na rzecz kleryków czy szerzej - Kościoła katolickiego, organa WSW postanowiły zainteresować SB konkretnymi lekarzami ${ }^{72}$.

Według kierownictwa WSW organa kontrwywiadu wojskowego od samego początku źle zorganizowały pracę $\mathrm{w}$ batalionach ratownictwa terenowego. Nie wytypowano oficerów obiektowych WSW w momencie organizowania jednostek. Nie opracowano także wśród kadry i szeregowych żołnierzy świeckich odpowiedniej liczby osobowych źródeł informacji. Przejęto ze znacznym opóźnieniem tajnych współpracowników wśród alumnów, którzy w wyniku reorganizacji znaleźli się w nowych jednostkach. Jak zaznaczał zastępca szefa WSW, płk. Jerzy Mrówczyński:

„Analiza jakości i pracy tych nielicznych tajnych współpracowników spośród alumnów drugiego rocznika służby, którzy nadal przebywają w wojsku wskazuje, że niektóre organy WSW chyba nie w pełni doceniają sens wytycznych szefa WSW [z 1965 r. przyp. B. K.] w sprawie dokonywania pozyskań wśród kleryków. W myśl wytycznych pozyskania, obok potrzeby rozpracowania środowiska alumnów w wojsku, powinny mieć przede wszystkim na celu przygotowanie odpowiedniej ilości tajnych współpracowników, których można by nadal wykorzystywać po ich powrocie do seminariów. Dotychczasowa jednak współpraca z nimi nie daje podstaw do trwałego związania ich we współpracy. Dostarczane przez nich meldunki czy przekazywane ustnie informacje dotyczą wyłącznie spraw ogólnie znanych o alumnach czy nawet żołnierzach świeckich"73.

Wobec tego zastępca szefa nakazał lepiej „kierunkować” agentów wśród alumnów, tak by udzielali szerszych informacji, a przede wszystkim przywiązywać ich do organów WSW, poprzez zbieranie na nich materiałów obciążających lub odpowiednie wynagrodzenie finansowe. Zarzut został postawiony również $\mathrm{SB}$, że nie organizowała pracy wśród alumnów powołanych do wojska, a także nie wspomagała organów WSW w typowaniu

72 AIPN, MSW, 0639/231, t. 2, Informacja [płk. Jerzego Mrówczyńskiego, zastępcy szefa WSW] o pracy komisji poborowych, badających zdolność alumnów do odbycia zasadniczej służby wojskowej, [Warszawa] 29 XI 1966 r., k. 155-158. Stamtąd też cytat.

${ }^{73}$ Cyt. AIPN, SWSW, 2386/19701, Pismo zastępcy szefa Wojskowej Służby Wewnętrznej, płk. Jerzego Mrówczyńskiego, nr BB-023/10/67, [Warszawa] 6 I 1967 r., k. 155. 
i przekazywaniu agentów ${ }^{74}$. Trudności te, ze względu na brak doświadczenia w pracy operacyjnej organów WSW występowały jednak ciągle ${ }^{75}$.

Alumnów podejrzewano o ujawnianie w korespondencji tajemnicy wojskowej - za taką uważano właściwie wszystko to, co działo się w jednostkach. Wobec tego każdą informację o służbie alumnów, zawartą w listach do rodziny, innych księży lub kleryków, traktowano jako ujawnienie tajemnicy. To spowodowało, że na żądanie WSW wprowadzono kontrolę korespondencji przez terenowe jednostki SB. Same organa rozwinęły intensywną pracę w celu wykrycia i udokumentowania takich „wykroczeń" alumnów, sięgając do podsłuchów, tajnych przeszukań oraz uczulenia osobowych źródeł informacji na to zagadnienie ${ }^{76}$. Poszczególne jednostki WSW prowadziły, w ramach kontrwywiadowczego zabezpieczenia jednostek, teczki zagadnieniowe dotyczące „klerykalizmu”. Mimo zebranych przez organa WSW drogą operacyjną dokumentów świadczących o „wykroczeniach" alumnów, Naczelna Prokuratura Wojskowa odstąpiła od postawienia komukolwiek zarzutów. Okazało się, że nawet w świetle przepisów prawa PRL brakło podstaw, by ukarać żołnierzy-kleryków za rzekome ujawnianie tajemnicy wojskowej ${ }^{77}$.

Kłopoty organów WSW z alumnami spowodowane były także troską Kościoła katolickiego o swoich przyszłych duszpasterzy. Alumni byli w seminariach przygotowywani przed wcieleniem do wojska, uodporniani na działania oficerów politycznych i zapewne ostrzegani przed organami WSW. Według kontrwywiadu wojskowego najbardziej aktywnymi klerykami okazali się studenci seminariów: krakowskiego, poznańskiego, przemyskiego i bagieńskiego. Oprócz nauki, alumni byli kontrolowani przez opiekunów wysyłanych do jednostek. Odwiedzali ich i wspierali także biskupi. Duchowni skonsolidowani w jednej jednostce łatwiej solidaryzowali się i wzajemnie pilnowali. Zarówno organa WSW, jak i aparat polityczny ubolewał, że alumnów nie da się „wychować”. Wśród powołanych do wojska połowa zaliczana była przez kontrwywiad wojskowy do grupy „wojujących kleryków” i „fanatyków religijnych", 20\% zachowywało się biernie ze względu na możliwe reperkusje w seminariach, a $30 \%$ udawało się zaangażować przełożonym w wojsku do pracy kulturalnej czy uczestnictwa w czynach społecznych ${ }^{78}$.

74 Ibidem, k. 156.

75 Ibidem, Pismo zastępcy szefa Wojskowej Służby Wewnętrznej, płk. Jerzego Mrówczyńskiego, nr BB-001203/10/67, [Warszawa] 30 V 1967 r., k. 182-183.

${ }^{76}$ Ibidem, Pismo zastępcy szefa Zarządu I Szefostwa Wojskowej Służby Wewnętrznej, płk. Jerzego Markuszewskiego, nr BB-0794/63/67, [Warszawa] 6 IV 1967 r., k. 164-165.

77 Ibidem, Pismo zastępcy szefa Wojskowej Służby Wewnętrznej, płk. Jerzego Mrówczyńskiego, nr BB-001461/27/67, [Warszawa] 7 VII 1967 r., k. 184.

78 Ibidem, 2386/21089, Informacja dot. alumnów odbywających służbę wojskową w okresie ostatnich 3 lat, [Warszawa] 26 VI 1973 r., k. 6-9. Stamtąd też cytat. Zob. też dokument 
Według ppłk. Adolfa Sieradzkiego negatywne opinie alumnów dotyczące służby wojskowej, które pojawiały się w listach do przełożonych, nie znajdowały odzwierciedlenia w rzeczywistości. W jego opinii żołnierze-klerycy byli mocno zdyscyplinowani, jednocześnie oczerniali wojsko, upewniając hierarchów kościelnych o represyjnym charakterze służby. Organa WSW zwróciły uwagę, że alumni radykalizowali się po odbyciu wizyt w jednostkach wojskowych ich opiekunów z seminariów i biskupów, którzy mieli im grozić wyrzuceniem z seminarium, jeżeli będą się w cokolwiek angażować w jednostce. Wobec tego wniosek organów kontrwywiadu wojskowego nasuwał się jeden: najgorsza była władza kościelna. Co ciekawe, odnośnie do kapelanów wojskowych organa WSW miały przychylną opinię, uważając, że nie interesują się specjalnie nabożeństwami dla żołnierzy i nie ingerują w służbę alumnów. Większość z nich została więc nazwana „księżmi-patriotami”79.

Organom WSW największy problem sprawiał werbunek alumnów na tajnych współpracowników, ponieważ przed przybyciem do jednosti byli przeszkalani w seminariach, a kontakty z WSW i przekazywanie informacji porównywano tam do działalności judaszowej. Wcielenie do wojska przedstawiane było jako „zemsta” za odmowę współpracy z pionem antykościelnym SB. To skutecznie odstraszało alumnów. Organa WSW powoływały się przy werbunku na odczucia patriotyczne, zabezpieczenie jednostki przed obcym wywiadem, zapobieżenie wybuchowi wojny, utrzymanie osiągnięć ekonomicznych kraju itp. Powody te oddziaływały na nich skutecznie ${ }^{80}$.

Według informacji zebranych przez organa WSW w latach 1970-1973 udało się zwerbować $w$ roli tajnych współpracowników 16 alumnów na 360 służących wtedy w wojsku, z czego 5 przekazano SB. 43 alumnów zrezygnowało

nr 2018 IV 1969 r. Notatka zastępcy szefa Wojskowej Stużby Wewnętrznej, płk. Czesława Kiszczaka dotyczaca alumnów 54. SBRT w latach 1968-1969 [w:] A. Lesiński, Stużba wojskowa..., s. 148-149. Na temat Czesława Kiszczaka zob. L. Kowalski, Cze.Kiszczak. Biografia gen. broni Czesława Kiszczaka, Poznań 2015.

79 Zob. dok nr 741963 grudzień 24, Wrocław - Pismo zastępcy komendanta wojewódzkiego MO do spraw SB we Wrocławiu do szefów oddziałów Wojskowej Służby Wewnętrznej w sprawie uniemożliwienia duchownym $z$ Wyższego Seminarium Duchownego we Wrocławiu świątecznych odwiedzin alumnów pelniących zasadnicza służbę wojskowa [w:] Metody pracy operacyjnej aparatu..., s. 356; AIPN, SWSW, 2386/21089, Pismo szefa Zarządu WSW SOW, płk. Eugeniusza Smolarczyka do szefa Zarządu II Szefostwa WSW nr B-0809/2 dot. sytuacji wśród alumnów 56. SBRT, [Wrocław] 16 IV 1975 r., k. 31-32. Przebieg służby płk. Eugeniusz Smolarczyka (ur. 3 V 1924 r. w Starej Wsi), zob. https://katalog.bip.ipn.gov.pl/ informacje/69668 (dostęp 15 IX 2020 r.).

80 AIPN, SWSW, 2386/21089, Informacja [płk. Stanisława Sasa, szefa Zarządu WSW WOW] o nastrojach i przebiegu służby alumnów odbywających zasadniczą służbę wojskową w 54 . szkolnym batalionie ratownictwa terenowego w Bartoszycach w okresie 28 X 1974-30 IV 1975 r., [Warszawa] 13 V 1975 r., k. 35-40. 
po odbyciu służby wojskowej z nauki w seminarium. Kontrwywiad wojskowy dostrzegał zmiany w postawach alumnów. Uważał, że większość pokorniała po dwóch latach indoktrynacji ideą komunistyczną. Z drugiej strony zauważano surowszy stosunek przyszłych księży do wyższego duchowieństwa. Alumni mieli być bardziej krytyczni w stosunku do Kościoła, „mniej czołobitni i ślepo posłuszni”. Ta postawa zadowalała organy WSW. Stąd wniosek nasuwał się jeden: „jeżeli powoływanie alumnów do odbywania służby wojskowej nie jest uwarunkowane względami politycznymi należałoby rozważać celowość dalszego stosowania tej praktyki" ${ }^{81}$. Trzeba też na marginesie zaznaczyć, że nie prowadzono statystyk osób zaufanych $(\mathrm{OZ})$ wyłonionych spośród żołnierzy-kleryków, a tych z racji mniej formalnej, luźnej współpracy mogło być więcej niż tajnych współpracowników.

Wobec sukcesów organów WSW i zadowalającej „ochrony” batalionów ratownictwa terenowego złożonych $\mathrm{z}$ alumnów zrezygnowano $\mathrm{z}$ wydzielonych oficerów kontrwywiadu wojskowego w tych jednostkach. Anulowano także wytyczne szefa WSW wprowadzone pismem nr A-0041 z 2 lipca 1965 r. oraz pismo szefa WSW nr BB-023/10/67 z 6 stycznia 1967 r. ${ }^{82}$ Od teraz pracę $\mathrm{z}$ alumnami oparto na ogólnych zasadach ujętych w instrukcji o pracy kontrwywiadowczej z $1971 \mathrm{r}^{83}$ Zabezpieczano też poszczególne bataliony podsłuchem lokalowym (PL) założonym w pomieszczeniu, gdzie alumni spotykali się z odwiedzającymi ich duchownymi i rodzinami. Zawsze stosowano także przegląd korespondencji (PK) wchodzącej i wychodzącej $\mathrm{z}$ batalionów szkolnych. Były to często jedyne formy bezpośredniego dotarcia do środowiska alumnów w przypadku niezwerbowania wśród nich osobowego źródła informacji ${ }^{84}$.

Odnotowano także postępy w rozpracowaniu księży z tzw. otoczenia. Zdobyte informacje o działalności tych księży, m.in. o przeróżnych spotkaniach,

${ }^{81}$ Ibidem, Informacja dot. alumnów odbywających służbę wojskową w okresie ostatnich 3 lat, [Warszawa] 26 VI 1973 r., k. 6-9. Stamtąd też cytaty. Zob. także: ibidem, 2386/30839, Ppłk Adolf Sieradzki, „Praca kontrwywiadowcza wśród alumnów powołanych do wojska, Oddział Kadr i Szkolenia Szefostwa WSW", Warszawa styczeń 1964 r., s. 10-11.

${ }^{82}$ Ibidem, 2386/21089, Szyfrogram wych[odzący] nr 1478 zastępcy szefa WSW, płk. Wiktora Siennickiego, [Warszawa] 14 VII 1973 r., k. 10. Przebieg służby płk. Wiktora Siennickiego (ur. 5 VII 1924 r. w Warszawie) zob. https://katalog.bip.ipn.gov.pl/informacje/36323 (dostęp 15 IX 2020 r.).

83 Zob. instrukcję o pracy kontrwywiadowczej Wojskowej Służby Wewnętrznej wprowadzoną zarządzeniem ministra obrony narodowej nr 005/MON z 25 II 1971 r. przedrukowane jako dokumenty nr 7 i 8 w Instrukcje o pracy kontrwywiadowczej..., s. 151-202.

84 AIPN, SWSW, 2386/21108, Notatka służbowa dot. sprawdzenia i oceny kontrwywiadowczego rozpoznania alumnów odbywających służbę w 54. sbrt w Bartoszycach, [Warszawa] 31 III 1980 r., k. 373. 
kochankach, kontach dolarowych, kontaktach z zagranicą itp. Szefostwo WSW przekazywało do Departamentu IV MSW ${ }^{85}$.

Przy okazji rozpracowywania środowiska kościelnego szersze informacje o kontaktach oficerów Sił Zbrojnych PRL z księżmi i Kościołem katolickim napływały do WSW. Najbardziej newralgiczne dla organów kontrwywiadu wojskowego było uczestnictwo oficerów i ich rodzin w nabożeństwach i uroczystościach kościelnych. Oficerowie WSW weryfikowali nawet listy z postulatami do władz, np. dotyczących budowy kościoła, i ustalali nazwiska oficerów bądź ich rodzin. Jeżeli syn oficera trafił do seminarium, oficer taki był wyrzucany z partii i wojska. Wojskowa Służba Wewnętrzna starała się odnotowywać wszystkie te przypadki i informować poszczególnych dowódców okręgów wojskowych/rodzajów sił zbrojnych, aby wyciągnęli odpowiednie konsekwencje ${ }^{86}$.

Jak pisał szef Wydziału WSW 6 Pomorskiej Dywizji Powietrzno-Desantowej w Krakowie, płk Marian Ziółkowski: „Garnizon krakowski, w którym stacjonują jednostki 6. PDPD należy do jednych z najbardziej uklerykalnionych w Polsce. Służy temu dobra i wyselekcjonowana kadra na czele z kardynałem Karolem Wojtyłą, zdecydowanym wrogiem socjalizmu w Polsce”. Pułkownik Ziółkowski miał prawo do narzekania, gdyż „nieposłuszna” kadra wojskowa brała udział w kampanii na rzecz budowy kościoła na Krowodrzy (146 rodzin wojkkowych, z czego 49 było członkami PZPR). Szef krakowskiego Wydziału WSW był oburzony słowami ówczesnego kardynała Karola Wojtyły, który będąc z wizytą duszpasterską w punkcie katechetycznym na Krowodrzy, miał powiedzieć: „Zaproście Gierka aby zobaczył w jakich warunkach się modlicie”. Ziółkowski uważał, że niektórzy żołnierze zawierali związki małżeńskie „wobec Boga”, młodzież skupiała się w duszpasterstwie akademickim, przyciągając dzieci z rodzin wojskowych (ponad 400 młodych ludzi z rodzin wojskowych studiowało wtedy na uczelniach). Wszystkie te elementy płk Ziółkowski wymieniał jako zagrożenie dla socjalizmu, uważając Kościół za największego wroga ${ }^{87}$.

Co ciekawe, największe kłopoty organa WSW miały z alumnami wywodzącymi się z Krakowa. W 56 SBRT wiódł prym szer. Tadeusz Isakowicz-Zaleski, który od początku swojej służby (październik 1975 r.) „naruszał

${ }^{85}$ Ibidem, 2386/21089, Pismo szefa Zarządu II Szefostwa WSW, płk. Władysława Mrowca nr BB-0019/33/74, dot. działalności kleru, [Warszawa] 8 I 1974 r., k. 16-17.

86 Ibidem, Pismo szefa Wojskowej Służby Wewnętrznej, gen. Teodora Kufla nr BB-01283/33/73 - Informacja dotycząca uprawiania praktyk religijnych przez kadrę zawodową i ich rodziny [sic!], [Warszawa] 5 X 1973 r., k. 11-15.

87 Ibidem, Wystąpienia szefa Wydziału WSW 6. PDPD w Krakowie, płk. Mariana Ziółkowskiego, na odprawie krajowej, [Warszawa] 21 XII 1976 r., k. 63-69. Stamtąd też cytaty. Zob. także: ibidem, Notatka służbowa szefa Wojskowej Służby Wewnętrznej, gen. Teodora Kufla dot. działalności kleru diecezji krakowskiej, [Warszawa] 2 VII 1974 r., k. 18-19. 
dyscyplinę", domagając się kaplicy dla alumnów, namawiając ich do głodówek, pisania zbiorczych listów do kardynała Stefana Wyszyńskiego i GZP WP z informacjami o sytuacji w jednostce, wyśmiewając na zajęciach politycznych dygnitarzy partyjnych. Za uporczywy sprzeciw wobec służby wojskowej i walkę z systemem był wielokrotnie karany aresztem (łącznie $40 \mathrm{dni})$. Przeprowadzono z nim szereg rozmów ostrzegawczych, angażując do tego nie tylko dowódcę batalionu, ale również oficerów WSW i prokuratorów z Wojskowej Prokuratury Garnizonowej w Opolu. Rozmowy te nie przynosiły skutków, przyszły duchowny był nieugięty, wkładając cały swój wysiłek „na osłabienie dyscypliny w wojsku oraz na walkę z komunizmem w Polsce". Podobną postawę według organów kontrwywiadu wojskowego prezentowało wielu żołnierzy-kleryków, jak szer. Wiesław Kanak, szer. Tadeusz Kowańczuk, szer. Jan Sowa, szer. Agaciak, szer. Wojciech Sowa, szer. Kolano, szer. Sarwa oraz szer. Wiktorowiczak ${ }^{88}$.

Tak wspomina swoją służbę ks. Tadeusz Isakowicz-Zaleski: „Na drugi dzień ostrzygli nas na pałę i rozdzielili po kompaniach. Ja dostałem przydział do 1. Drużyny 1. Plutonu 1. Kompanii [...]. W Brzegu były dwie kompanie kleryckie, tworzące samodzielny batalion ratownictwa terenowego [...]. Byli wśród nas tak zwani braci podłączeni, czyli «kable»: połowę stanowili klerycy (mówiono o nas: żołnierze alumni), a połowę oni. Byli to często aktywiści partyjni lub działacze ZMS-u”. A dalej: „Ale mieliśmy też rozmowy z tak zwanym Jasiem Gumowe Ucho, czyli oficerem kontrwywiadu, i oficerami politycznymi. Na cały batalion przypadało kilku oficerów politycznych, więcej niż w innych jednostkach. Próbowano nas «rozmiękczać», proponowano na przykład różne fuchy w kuchni czy w bibliotece, żeby zyskać naszą życzliwość" 89 .

Dla zilustrowania problemów z werbunkiem kleryków na tajnych współpracowników warto przedstawić przykład z 56 SBRT. Organa WSW tłumaczyły

88 Ibidem, Pismo zastępcy szefa Zarządu WSW SOW, płk. Stanisława Torebko, dot. alumnów 56. SBRT, [Wrocław] 3 III 1977 r., k. 70-75. Stamtąd też cytat. Zob. także: ibidem, 2386/16922, Informacja szefa Oddziału WSW w Opolu, płk. Zdzisława Cichego, [Opole] 4 V 1977 r., k. 15-16. Ks. Isakowicz-Zaleski potwierdza te słowa: „Nie ukrywam, w wojsku należałem do grupy najbardziej zbuntowanych. Wiele razy trafiłem do aresztu, spędziłem tam w sumie dwa miesiące, dokładnie pięćdziesiąt sześć dni. Pierwsza kara - nie pamiętam już za co - to było pięć dni. Potem często dostawałem karę nie dlatego, że sam coś przeskrobałem, ale dla «zasady»: grupa się zbuntowała, czegoś nie zrobiła, więc wybranych, «podpadniętych» wsadzano do aresztu”. Cyt. za: T. Isakowicz-Zaleski, Moje życie nielegalne, współpraca W. Bonowicz, Kraków 2008, s. 30-31. Pułkownik Torebko był zwolennikiem wysłania alumnów pokroju ks. Isakowicza-Zaleskiego i ks. Kanaka do oddziałów dyscyplinarnych. Przebieg służby płk. Stanisława Torebki (ur. 13 I 1932 r. w Szelągówce) zob. https:// katalog.bip.ipn.gov.pl/informacje/105845 (dostęp 15 IX 2020 r.) płk. Zdzisława Cichego (ur. 1 VII 1925 r. w Sosnowcu) zob. https://katalog.bip.ipn.gov.pl/informacje/636242 (dostęp 15 IX 2020 r.).

89 Cyt. za: T. Isakowicz-Zaleski, Moje życie nielegalne..., s. 25-26, 28-29. 
to „niekorzystnym oddziaływaniem kleru” na alumnów i radykalizacją ich poglądów. Pomimo trudności z werbunkiem batalion ten w 1975 r. „zabezpieczało" trzech TW i dwie OZ ${ }^{90}$. Później, w okresie 1977-1979, w batalionie tym dalej były dwie OZ i czterech TW (dwóch wśród kadry w pododdziałach i dwóch niewywodzących się z kleryków) ${ }^{91}$. W tym czasie jedną OZ miał być szer. Stanisław Jarosz ${ }^{92}$, a drugą OZ szer. Andrzej Szymankiewicz ${ }^{93}$.

90 AIPN, SWSW, 2386/21089, Pismo zastępcy szefa Zarządu WSW SOW, płk. Stanisława Torebko, dot. alumnów 56. SBRT, [Wrocław] 3 III 1977 r., k. 73-74. Stamtąd też cytat. Pułkownik Torebko informował Szefostwo WSW, że: „Z dotychczasowej praktyki wiadomo, że większość pozyskanych TW w tym środowisku liczy na określone korzyści materialne (doraźną pomoc finansową) względnie za udzielanie pomocy organom WSW otrzymanie urlopów i przepustek. Te zainteresowania materialne w pełni wykorzystujemy". Cyt. ibidem, k. 74 .

${ }^{91}$ Ibidem, Pismo nr B-02811 szefa Zarządu WSW SOW, płk. Eugeniusz Smolarczyka do szefa Zarządu II Szefostwa WSW, [Wrocław], 20 X 1978 r., k. 104; 2386/16922, Informacja dot. sytuacji wśród alumnów 56. SBRT w Brzegu, [Opole] 17 X 1978 r., k. 23.

92 Stanisław Jarosz (ur. 31 X 1958 r. w Sokołowie Małopolskim). Służył w 56 SBRT od listopada 1977 r. do października 1979 r., w 1981 r. wystąpił z WSD w Przemyślu i podjął naukę w Wyższym Seminarium Zagranicznym dla Polonii w Poznaniu, skąd wystąpił w 1983 r. Zarejestrowany 2 XII 1977 r. przez Wydział IV KWMO w Przemyślu do ewidencji operacyjnej księży o nr 44208 i rozpracowywany w ramach TEOK (materiały zniszczone w 1990 r.). Przyjęty 1 II 1985 r. do służby na stanowisko inspektora SB w Wydziale IV WUSW w Krośnie, następnie w Rejonowym Urzędzie Spraw Wewnętrznych w Krośnie, zwolniony na własną prośbę 30 IV 1986 r. Pozyskany 9 V 1986 r. przez Wydział IV WUSW w Krośnie i zarejestrowany w kategorii tajnego współpracownika ps. „Skorpion” o nr 8510. Zob. AIPN, MSW, 003322/1, Karta o symbolu EOK-6/63 z kartoteki księży katolickich dot. Stanisława Jarosza; 1437/2, Karta o symbolu E-59 z kartoteki księży katolickich dot. Stanisława Jarosza; 2460/1, Karta o symbolu Ko-14 z kartoteki funkcjonariuszy dot. Stanisława Jarosza; 2912/1, Karta o symbolu EO-4/77 i dwie karty o symbolu Mkr-2 z kartoteki odtworzeniowej dot. Stanisława Jarosza; Archiwum Instytutu Pamięci Narodowej w Rzeszowie (dalej: AIPN Rz), Wojewódzki Urząd Spraw Wewnętrznych w Krośnie (dalej: WUSW w Krośnie), 490/1, Karta o symbolu Ko-14 z kartoteki funkcjonariuszy dot. Stanisława Jarosza; 0084/883, t. 1-2, Teczka personalna i pracy tajnego współpracownika ps. „Skorpion” [1986-1988]; 0085/60, Akta personalne funkcjonariusza SB, Jarosza Stanisława [1983-1986]; Archiwum Instytutu Pamięci Narodowej w Poznaniu (dalej: AIPN Po), Wojewódzki Urząd Spraw Wewnętrznych w Poznaniu (dalej: WUSW w Poznaniu), 0044/1, Karta o symbolu E-16 z kartoteki ogólnoinformacyjnej i odtworzeniowej dot. Stanisława Jarosza; AIPN Rz, Wojewódzki Urząd Spraw Wewnętrznych w Rzeszowie (dalej: WUSW w Rzeszowie), 00112/1, Karty o symbolu EO-4/77, EO-4A/77 i Mkr-2 z kartoteki ogólnoinformacyjnej dot. Stanisława Jarosza. O działalności Jarosza zob. też AIPN, SWSW, 2386/21089, Pismo nr B-02811 szefa Zarządu WSW SOW, płk. Eugeniusza Smolarczyka do szefa Zarządu II Szefostwa WSW, [Wrocław] 20 X 1978 r., k. 103.

93 Ksiądz kanonik Andrzej Szymankiewicz (ur. 23 IX 1958 r. w Ostrowie Wielkopolskim). Służył w 56 SBRT od listopada 1977 r. do października 1979 r. Ukończył WSD w Poznaniu. Później m.in. wikary parafii pw. św. Marii Magdaleny w Czarnkowie, następnie wikary parafii pw. św. Andrzeja Apostoła w Nekli i proboszcz parafii pw. św. Marii Magdaleny w Krotoszynie. Zarejestrowany 4 X 1977 r. przez Wydział IV KWMO w Poznaniu do ewidencji operacyjnej księży o nr 43810 i rozpracowywany w ramach TEOK. Zob. AIPN Po, WUSW w Poznaniu, 
Dodatkowo przez okres 1969-1980 Wydział WSW w Opolu „ochraniał” batalion złożony z alumnów przez tajnych współpracowników ps. „Danek” (w 1 kompanii), „Hrabia” (w 2 kompanii), „Edyta” (w sztabie 56 Batalionu), „Bratek” (zabezpieczenie PTG - pływającego transportera gąsienicowego), "Lotos” (w 2 kompanii), „Ula” (alumn pozyskany w 1979 r.) oraz OZ: Adama Szpechta (podoficer ewidencji), Ryszarda Wierzbę (szef kompanii) i Jana Jankowskiego (uzbrojeniowiec) ${ }^{94}$. Dla porównania w 1978 r. dla „zabezpieczenia” 54 SBRT wykorzystywano jednego nieoficjalnego pracownika (NP), sześciu TW (dwóch wywodzących się z kleryków, dwóch spośród aktywistów i dwóch spośród kadry) oraz dwie OZ. Jak informowały organa WSW: „Pewne problemy nastręcza współpraca TW spośród alumnów. Uzyskane od nich informacje dotyczą głównie żołnierzy aktywistów i kadry jednostki. Udzielają natomiast skąpych informacji o innych alumnach, jak również o tym, co się dzieje na plebanii, czy też podczas spotkań z przedstawicielami kleru. Swoje stanowisko motywują tym, że na współpracę zgodzili się z pobudek patriotycznych, gdyż widzą potrzebę zabezpieczenia wojska przed rozpoznaniem przeciwnika. Natomiast to co się dzieje wśród alumnów stanowi wewnętrzną sprawę kościoła i nie zagraża ich zdaniem naszej obronności"95. W 1979 r. było pięciu TW (dwóch z kadry, dwóch „aktywistów”, jeden pracownik cywilny), cztery OZ (dwóch podoficerów i dwóch alumnów) oraz jeden NP ps. „Wanda” (jeszcze jako TW w kwietniu 1979 r. przeniesiony z 1 Warszawskiej Brygady Saperów) ${ }^{96}$.

848/4, Karta o symbolu E-17 ze zbioru kart koordynacyjnych dot. Andrzeja Szymankiewicza; AIPN, MSW, 2912/1, Karta o symbolu EOK-6-A z kartoteki odtworzeniowej dot. Andrzeja Szymankiewicza; 1437/2, Karta o symbolu E-59 z kartoteki księży katolickich dot. Andrzeja Szymankiewicza; 003322/1, Karta o symbolu EOK-6/63 z kartoteki księży katolickich dot. Andrzeja Szymankiewicza.

94 AIPN, SWSW, 2386/16922, Wykaz tajnych współpracowników, [Opole] b.d., k. 1; Wykaz osób zaufanych na obiekcie 56. SBRT, [Opole] b.d., k. 3. Według „Centralnego rejestru agentury i właścicieli lokali konspiracyjnych WSW” pod nr 19708 zarejestrowany w kategorii TW ps. „Hrabia” został 27 IV 1969 r. przez Oddział WSW Opole Bolesław Uszyński, a pod nr 42240 zarejestrowana w kategorii TW ps. „Edyta” została 14 VIII 1978 r. przez Oddział WSW Opole Maria Mazurkiewicz. Zob. ibidem, 003200/2, Centralny rejestr agentury i właścicieli lokali konspiracyjnych WSW nr 12950-25859 [za lata 1965-1972], b.m., b.d., k. 265; 003200/4, Centralny rejestr agentury i właścicieli lokali konspiracyjnych WSW nr 38761-51658 [za lata 1977-1981], b.m., b.d., k. 137. Brak możliwości identyfikacji pozostałych osobowych źródeł informacji. Dodatkowo informacji dostarczał TW ps. „Grażyna”. Zob. ibidem, 2386/21089, Pismo zastępcy szefa Zarządu WSW SOW, płk. Stanisława Torebko, dot. alumnów 56. SBRT, [Wrocław] 3 III 1977 r., k. 73.

${ }^{9}$ Ibidem, 2386/21089, Pismo nr B-02013 zastępcy szefa Zarządu WSW POW, płk. Antoniego Kubickiego do szefa Zarządu II Szefostwa WSW, Bydgoszcz 25 X 1978 r., k. 106. Stamtąd też cytat.

${ }_{96}$ Brak było osobowych źródeł informacji wśród alumnów. Zob. ibidem, 2386/16922, Notatka służbowa z kontroli pracy pomocnika szefa Wydziału I Oddziału WSW w Opolu, [Opole] 
Rok 1978 przyniósł wybór Karola Wojtyłę na biskupa Rzymu, co spowodowało zaktywizowanie działalności Kościoła katolickiego w Polsce. W tym czasie w dwóch batalionach służyło 117 alumnów (60 w 54 SBRT i 57 w 56 SBRT). Klerycy otrzymali instrukcje z seminariów, by nie angażować się w żadną działalność w jednostkach, zwłaszcza polityczną czy kulturalno-oświatową (jak Drużyny Przodujących Żołnierzy). Dochodziło nawet do relegowania $z$ uczelni, jeżeli aktywność alumnów w wojsku była zbyt duża. Jednocześnie klerycy-żołnierze nakłaniali „aktywistów” do udziału w modlitwach czy pogadankach światopoglądowych ${ }^{97}$. Kolejny rok przyniósł pielgrzymkę papieża do Polski. W czasie przybycia Jana Pawła II do kraju zaplanowano dla żołnierzy służby zasadniczej ćwiczenia na poligonach, by ci nie próbowali masowo składać podań o wyjście na przepustkę na czas pielgrzymki papieskiej. To właśnie z 56 SBRT żołnierze-klerycy chcieli się udać do Częstochowy, by tam przywitać Jana Pawła II. Jednak dowództwo batalionu na ten okres zaplanowało ćwiczenia w obozie w Żaganiu. Ostatecznie pozwolono alumnom udać się do Częstochowy, ale w ubraniach cywilnych. W tym czasie WSW miała zresztą za zadanie pilnować, aby żaden umundurowany żołnierz nie pojawił się pod ołtarzem w czasie koncelebracji mszy ${ }^{98}$.

Wybór papieża-Polaka utrudnił pracę operacyjną organów WSW w batalionach szkolnych. Alumni-żołnierze nie chcieli podejmować współpracy z kontrwywiadem wojskowym. Co więcej, nasiliły się głodówki i pisanie petycji do Episkopatu Polski o poparcie, a do pionu politycznego wojska o zmiany warunków służby w jednostkach i metod stosowanych wobec kleryków przez przełożonych wojskowych. Żądano także zaprzestania politycznej indoktrynacji przez oficerów pionu politycznego Sił Zbrojnych PRL ${ }^{99}$. Wychodząc z wojska w październiku 1979 r. do rezerwy, alumni z 56 SBRT nie przyjęli tradycyjnych chust $\mathrm{z}$ jednostki, a założyli chusty wykonane poza koszarami, z herbem papieskim i napisami: „Bóg - rezerwa - honor - Ojczyzna”, „Alumni z Papieżem - Papież Jan Paweł z alumnami żołnierzami” oraz „Ojciec Święty

5 III 1979 r., k. 109-110; Meldunek do Zarządu WSW SOW, [Opole 1979 r.], k. 132-132v.

${ }_{97}$ Ibidem, 2386/21089, Pismo nr BB-Pf 1184/33/78 szefa Wojskowej Służby Wewnętrznej, gen. Teodora Kufla do szefa GZP WP, gen. Włodzimierza Sawczuka, [Warszawa] 28 XI 1978 r., k. $124-127$.

98 B. Kapuściak, Kontrwywiad wojskowy PRL wobec wizyty Jana Pawła II w kraju w 1979 r., https://przystanekhistoria.pl/pa2/teksty/55464,Kontrwywiad-wojskowy-PRL-wobec-wizyty-Jana-Pawla-II-w-kraju-w-1979-r.html (dostęp 15 IX 2020 r.); AIPN, SWSW, 2386/16922, Pismo nr D-0744/3 szefa Oddziału WSW Opole do zastępcy szefa Zarządu WSW SOW szefa Oddziału III dot. sytuacji w 56. SBRT, [Opole] 17 IV 1979 r., k. 116-117.

99 AIPN, SWSW, 2386/21089, Pismo nr D-0562 szefa Zarządu WSW POW, płk. Antoniego Kubickiego do zastępcy szefa WSW - szefa Zarządu III Szefostwa WSW, Bydgoszcz 15 III 1979 r., k. 292-293; 2386/20541, Ocena sytuacji w związku z wizytą papieża, [Warszawa] 1 VI 1979 r., k. 137-144. 
z żołnierzami alumnami”100. Wizyta papieża w kraju nasiliła „klerykalizm” w wojsku. Wobec tego organa WSW miały sporo pracy, by wyśledzić wojskowych (wraz z rodzinami), którzy uczęszczali teraz na msze święte, przyjmowali księdza w domu czy pragnęli wziąć ślub kościelny lub ochrzcić dziecko. Oddziaływanie nie tylko autorytetu Jana Pawła II, ale także kard. Stefana Wyszyńskiego czy kard. Franciszka Macharskiego miało spore zasługi. Organom WSW pozostał w 1980 r. do „ochrony” tylko jeden batalion szkolny. Reszta została już rozformowana. W związku z tym 54 SBRT w Bartoszycach skupiał teraz największą uwagę kontrwywiadu wojskowego, tym bardziej, że alumni odmawiali udziału w komisjach wyborczych i ograniczyli spożycie posiłków ze względu na trwający czas pasyjny ${ }^{101}$. W tym czasie w batalionie służyło 100 „aktywistów” i 101 alumnów (19 wcielonych w 1978 r., 82 w 1979 r.) skupionych w trzech kompaniach. „Zabezpieczał” go jeden NP, czterech TW i dwie OZ, wywodzące się z kadry zawodowej i „aktywistów”102.

Ostatecznie zarządzeniem Pf-3 ministra obrony narodowej z 2 kwietnia 1980 r. przedterminowo zwolniono wszystkich alumnów z odbywania służby zasadniczej w 54 SBRT w terminie 10-15 kwietnia tr., przenosząc ich do rezerwy bez względu na czas odbytej służby ${ }^{103}$. W ten sposób zakończyła się służba kleryków-żołnierzy trwająca od 1959 r.

\section{Podsumowanie}

Z zachowanych w niewielkiej liczbie materiałów po byłej Wojskowej Służbie Wewnętrznej rysuje się ponury obraz walki organów kontrwywiadu wojskowego, przy ścisłej współpracy z pionem politycznym Sił Zbrojnych PRL, z Kościołem katolickim.

Walkę tę można podzielić na trzy okresy. Pierwszy to lata 1959-1964, gdy organa WSW kompletnie nie radziły sobie z problemem powołania alumnów

100 Ibidem, 2386/21089, Meldunek szefa Wojskowej Służby Wewnętrznej, gen. Czesława Kiszczaka do ministra ON, gen. Wojciecha Jaruzelskiego dot. zachowania się alumnów zwalnianych do rezerwy z 56. szkolnego batalionu ratownictwa terenowego, Warszawa 17 X 1979 r., k. 331-333.

101 Ibidem, 2386/21108, Informacja Szefostwa Wojskowej Służby Wewnętrznej, Warszawa 14 III 1980 r., k. 362-363; Plan wyjazdu do oficera KW ochraniającego 54. szkolny batalion ratownictwa terenowego w Bartoszycach, w którym odbywają służbę wojskową alumni WSD, [Warszawa] 11 III 1980 r., k. 367-370.

102 Ibidem, Notatka służbowa dot. sprawdzenia i oceny kontrwywiadowczego rozpoznania alumnów odbywających służbę w 54. sbrt w Bartoszycach, [Warszawa] 31 III 1980 r., k. 371-373.

${ }^{103}$ Ibidem, Zarządzenie ministra obrony narodowej [podpisane w zastępstwie przez gen. Floriana Siwickiego, wiceministra ON] nr Pf-3 w sprawie przedterminowego zwolnienia z wojska podoficerów i szeregowych odbywających zasadniczą służbę wojskową w 54 . Szkolnym Batalionie Ratownictwa Terenowego, Warszawa 2 IV 1980 r., k. 379-380. 
do wojska, jednocześnie próbowały wejść we współpracę z organami SB, same jednak specjalnie nie przekazywały swojej agentury cywilnym organom bezpieczeństwa państwa. Rozproszenie kleryków po licznych jednostkach utrudniało ich werbunek, ale ułatwiało ich „osłonę” poprzez agenturę wywodzącą się z żołnierzy służby zasadniczej.

Drugi okres to lata 1965-1966, kiedy organa WSW kładły silny nacisk na konkretne porozumienie z SB i jednocześnie same normowały wytyczne (1965 r.) dotyczące rozpracowania alumnów. W tym okresie klerycy-żołnierze byli skupiani najpierw w sześciu, a następnie w trzech tylko pododdziałach. W organach WSW pojawił się pomysł rozpracowywania parafii przy jednostkach złożonych z kleryków i środowiska diecezjalnego. Jednocześnie kontrwywiad wojskowy przekazywał zwerbowanych tajnych współpracowników Departamentowi IV MSW. Jak sugerują organa WSW, „powołanie kleryków do wojska utraciło charakter represyjny i obecnie odbywa się przy pełnym zastosowaniu zasady powszechności służby wojskowej. Jest to czynnik sprzyjający wychowaniu ich w duchu patriotycznym"104.

Lata 1966-1980 przynoszą zmianę w sposobie walki organów WSW z alumnami. Unormowanie zasad pracy operacyjnej w środowisku kleryków-żołnierzy jeszcze jednym pismem zastępcy szefa WSW (1967 r.) pomogło organom kontrwywiadu wojskowego wypracować model „ochrony” batalionów szkolnych. Skupienie alumnów w trzech specjalnie do tego utworzonych pododdziałach przyniosło, co prawda, dopiero od 1970 r., pewne sukcesy ${ }^{105}$. Przede wszystkim łatwiej było organom WSW spenetrować tak małe jednostki i spacyfikować wraz z GZP WP najbardziej aktywnych alumnów. Doraźne osiągnięcia odnoszone były także na polu agenturalnym, gdzie organa, kontrwywiadu wojskowego werbowały żołnierzy-kleryków pod pretekstami obrony ojczyzny oraz ochrony Sił Zbrojnych przed wrogiem wewnętrznym i zewnętrznym. Od 1973 r. nastąpiło wobec tego anulowanie wytycznych szefa WSW odnoszących się do rozpracowania alumnów. Praca operacyjna wśród kleryków odbywała się teraz na zasadach ogólnych, według instrukcji o pracy kontrwywiadowczej z 1971 r. Trzeba jednak zauważyć, że o ile przełom lat sześćdziesiątych-siedemdziesiątych XX w. był dla organów WSW pomyślny, jeżeli chodzi o werbunek osobowych źródeł informacji wśród alumnów, to już od jesieni 1978 r. praca operacyjna w batalionach szkolnych została mocno osłabiona. Powodem tego był prawdopodobnie wybór Karola Wojtyły na papieża.

\footnotetext{
104 Cyt. za Ibidem, 2386/19700, Projekt zarządzenia dyrektora Departamentu IV MSW i zastępcy szefa WSW, Warszawa styczeń 1965 r., k. 190.

105 Innego zdania jest Lech Kowalski, który tak pisze: „Werbunki agenturalne WSW wśród alumnów były pozytywnie oceniane przez Departament IV MSW. Później było już tylko gorzej. Kościół skutecznie ostrzegał młodych kleryków przed zakusami WSW i SB i pozyskiwanie nowych źródeł było o wiele trudniejsze”. Cyt. za L. Kowalski, Krótsze ramię Moskwy..., s. 234.
} 
W latach 1959-1980 organa WSW próbowały ściśle współpracować z SB. Początkowo domagały się od organów cywilnych przesyłania materiałów oraz doraźnej pomocy w werbunku alumnów. Zwerbowani w trakcie służby wojskowej agenci nie byli jednak przekazywani cywilnym organom reprsji. Zmieniło się to $z$ czasem i tajni współpracownicy czy chociażby osoby zaufane wywodzące się z alumnów-żołnierzy były przekazywani SB. Przesyłane były także informacje zdobyte od agentów wywodzących się ze środowiska alumnów, nie tylko dotyczące samych kleryków przebywających w jednostkach wojskowych, ale przede wszystkim wiadomości z życia poszczególnych kurii i ogólnie Kościoła katolickiego. Organa WSW co najmniej od lat siedemdziesiątych XX w. prowadziły na każdego alumna teczkę z adnotacjami o nim i donosami na niego. Materiały te były przekazywane do terenowych Wydziałów IV SB po wyjściu alumna z wojska do rezerwy ${ }^{106}$. Organa SB do końca służby alumnów, tj. do 1980 r., opieszale współpracowały z kontrwywiadem wojskowym, nie udzielając lub często udzielając z opóźnieniem informacji o alumnach.

Przez cały okres wcielania do wojska alumnów organa WSW realizowały wytyczne GZP WP, jednocześnie były przez oficerów politycznych mocno wspierane. Pion polityczny wojska organizował na szeroką skalę pogadanki i spotkania „wychowawcze”, na których dochodziło do indoktrynacji przyszłych duchownych. Liczba tych spotkań była specjalnie zwiększona, aby za wszelką cenę dotrzeć do młodych kleryków i wpoić im komunistyczne poglądy oraz pokazać wyższość świeckiego życia. O ile GZP WP udało się zniechęcić część alumnów do ukończenia seminarium, a organom WSW zwerbować wśród nich agentów, to skala tych przedsięwzięć była minimalna w porównaniu do liczby wcieleń kleryków do „ludowego” Wojska Polskiego.

Co więcej, bardzo często alumni kończący służbę wojskową byli bardziej uodpornieni na propagandę komunistyczną. Ich wiara była zahartowana. Stanowili w końcu według pionu politycznego i organów WSW trzon księży ideowych, „niepokornych”. Wydaje się, że GZP WP, chcąc osłabić Kościół katolicki wieloletnim wcielaniem kleryków do wojska, wzmocnił tylko tę instytucję, weryfikując - poprzez służbę wojskową - przyszłych księży ${ }^{107}$.

\section{Bibliografia}

\section{Archiwalia}

Archiwum Akt Nowych

Komitet Centralny Polskiej Zjednoczonej Partii Robotniczej

106 Materiały te weszły zapewne do teczek operacyjnych na księdza (TEOK) zakładanych już alumnom przez SB i uzupełniały ich wiedzę z okresu służby alumnów w wojsku.

107 Innego zdania jest ks. Isakowicz-Zaleski. Zob. T. Isakowicz-Zaleski, Moje życie nielegalne..., s. 37-38. 
Archiwum Instytutu Pamięci Narodowej

Ministerstwo Spraw Wewnętrznych

Szefostwo Wojskowej Służby Wewnętrznej

Zbiór akt personalnych żołnierzy pełniących służbę w cywilnych i wojskowych organach bezpieczeństwa państwa (w tym żołnierzy represjonowanych z motywów politycznych) oraz pracowników cywilnych wojska

Archiwum Instytutu Pamięci Narodowej w Lublinie

Wojewódzki Urząd Spraw Wewnętrznych w Białej Podlaskiej

Archiwum Instytutu Pamięci Narodowej w Poznaniu

Wojewódzki Urząd Spraw Wewnętrznych w Poznaniu

Archiwum Instytutu Pamięci Narodowej w Rzeszowie

Wojewódzki Urząd Spraw Wewnętrznych w Krośnie

Wojewódzki Urząd Spraw Wewnętrznych w Rzeszowie

Centralne Archiwum Wojskowe Wojskowego Biura Historycznego

Główny Zarząd Polityczny Wojska Polskiego

\section{Wydawnictwa źródłowe}

Instrukcje pracy kontrwywiadowczej Wojskowej Służby Wewnętrznej wraz z instrukcjami prowadzenia dokumentacji i ewidencji (1957-1990), wstęp i oprac. B. Kapuściak, Kraków 2010.

Instrukcje, wytyczne, pisma Departamentu IV Ministerstwa Spraw Wewnętrznych z lat 1962-1989. Wybór dokumentów, red. i oprac. A. Dziurok, F. Musiał, Kraków-Katowice 2017.

\section{Publikacje}

Aparat bezpieczeństwa w Polsce. Kadra kierownicza, t. II: 1956-1975, red. P. Piotrowski, Warszawa 2006.

Bobulski S., Klerycy - marynarze. Westerplatte 1964-1966 na tle przemian Kościoła w Polsce po II wojnie światowej, Kraków 2013.

Celmer M., Służba wojskowa alumnów Wyższego Seminarium Duchownego w Płocku w latach 1965-1980. Zarys problemu, „Studia Płockie” 2012, t. 40.

Cenckiewicz S., Geneza Ludowego Wojska Polskiego 1943-1945, Warszawa 2017.

Ciemięga K., Alumni w Wojsku Polskim w latach 1959-1980 w świetle dokumentów Głównego Zarządu Politycznego Wojska Polskiego, „Biuletyn Wojskowej Służby Archiwalnej” 2006.

Czwołek A., Służba wojskowa alumnów w PRL (na przykładzie 54. Szkolnego Batalionu Ratownictwa Terenowego w Bartoszycach), „Klio” 2011, nr 3.

Dziurok A., „Ignorować Wyszyńskiego. My go przeżyjemy i zwyciężymy”. Notatka z wykładu wicedyrektora Departamentu IV MSW płk. Zenona Gorońskiego z kwietnia 1969 r., „Aparat Represji w Polsce Ludowej 1944-1989” 2006, nr 2 (4).

Fitych T., Służba wojskowa alumnów w PRL, „Chrześcijanin w świecie” 1994, nr $1 / 196$. 
Frątczak W., Służba wojskowa alumnów diecezji włocławskiej jako forma represji wobec Kościoła, „Ateneum Kapłańskie” 2005, t. 144, z. 1 (575).

Frątczak W., Stużba wojskowa kleryków JW. 4413 w Bartoszycach w latach 19681970, Włocławek 2015.

Gabański S., Dobrze! Zapiski kleryka - żołnierza (1965-1967), Kraków 2013.

Isakowicz-Zaleski T., Moje życie nielegalne, współpraca W. Bonowicz, Kraków 2008. Janowski J., Alumni-żotnierze. Elementy formacji seminaryjnej w świadomości alumnów-żołnierzy na podstawie analizy dokumentów osobistych, Świdnica 2007.

Jarząbek W., PRL w politycznych strukturach Układu Warszawskiego w latach 1955-1980, Warszawa 2008.

Jubileuszowe spotkanie byłych alumnów, którzy w latach 1959-1981 pełnili służbe wojskowa. Deo et patriae, Warszawa-Modlin, 17-18 października 1997 roku, Warszawa 1998.

Kapłon M., Służba wojskowa kleryków Wyższego Seminarium Duchownego w Przemyślu jako jeden z elementów represji komunistycznych [w:] Kościół katolicki w Europie Środkowo-Wschodniej w obliczu dwóch totalitaryzmów (1917-1990), t. II, red. M. Krzysztofiński, J. Wołczański, Rzeszów-Lwów 2017.

Kapuściak B., Celowe niszczenie czy przepisowe brakowanie? Glosa w sprawie nieistniejacych materiałów po Głównym Zarządzie Informacji $i$ Wojskowej Służbie Wewnętrznej, „Przegląd Archiwalny Instytutu Pamięci Narodowej” 2018, t. 11.

Kompanie kleryckie w Wojsku Polskim 1959-1980. Materiały z konferencji naukowej zorganizowanej w 5. Pułku Inżynieryjnym w Szczecinie-Podjuchach 8-9 września 2008 r., red. J. Kornek, T. Krawczak, J. Macholak, Szczecin 2009. Kowalski L., Cze.Kiszczak. Biografia gen. broni Czesława Kiszczaka, Poznań 2015. Kowalski L., Krótsze ramię Moskwy. Historia kontrwywiadu wojskowego PRL, Warszawa 2017.

Krogulski L. M., Okupacja w imię sojuszu. Armia Radziecka w Polsce 1944-1956, Warszawa 2000.

Krogulski L. M., Okupacja w imię sojuszu. Armia Radziecka w Polsce 1956-1993, Warszawa 2001.

Larysz P., Służba wojskowa alumnów Śląskiego Seminarium Duchownego w latach 1959-1978, Katowice 2009.

Lesiński A., Służba wojskowa kleryków w PRL (1959-1980), Olsztyn 1995.

Marcinkiewicz-Kaczmarczyk A., Wojskowa Służba Wewnętrzna. Organizacja i zakres zadań [w:] Archiwalia komunistycznego aparatu represji - zagadnienia źródłoznawcze, pod red. F. Musiała, Kraków 2012.

Metody pracy operacyjnej aparatu bezpieczeństwa wobec kościołów i związków wyznaniowych 1945-1989, red. A. Dziurok, Warszawa 2004.

Mundur i sutanna, red. S. Pawłowski, Kraków 1998.

Myszor J., Służba wojskowa alumnów Wyższego Śląskiego Seminarium Duchownego w latach 1959-1979 [w:] Wojskowa służba śląskich duchownych w latach 1918-1980, red. Z. Kapała, J. Myszor, Katowice 1999. 
Paszkowski S., Służba wojskowa kleryków w latach 1959-1980. Jerzy Popiełuszko - alumn żołnierz, „Wrocławski Przegląd Teologiczny” 2010, nr 1.

Peterman R., Niszczenie akt GZI $i$ WSW [w:] Niepodległość ma jeden kształt. Antoniemu Macierewiczowi w 70. rocznice urodzin, Warszawa 2018.

Piotrowski P., Służba wojskowa kleryków na przykładzie 56. Batalionu Ratownictwa Terenowego w Brzegu (1966-1980) [w:] Represje wobec Kościoła katolickiego na Dolnym Śląsku i Opolszczyźnie 1945-1989, red. S. A. Bogaczewicz, S. Krzyżanowska, Wrocław 2004.

Pióro T., Alumni pod bronią (1959-1980), „Więź” 1997, nr 1.

Pót wieku Milenium. Religijne, polityczne i społeczne aspekty obchodów tysiąclecia Chrztu Polski (1956-1966/1967), red. B. Noszczak, Warszawa 2017;

Przed 50. laty. Wyrwani z seminariów Alumni-Żołnierze Brzeg n. Odra 1967-1969, praca zbiorowa, Brzeg 2017.

Schowaj miecz. Obiekcje sumienia w sprawie służby wojskowej. Materiały z sympozjum irenologicznego w Łodzi-Łagiewnikach 17-19 listopada 1989 roku, red. S. C. Napiórkowski, W. Koc, Niepokalanów 1993.

Setlak A., Służba wojskowa alumnów WSD w PRL $i$ jej ocena w wypowiedziach alumnów i kapłanów rezerwistów z 1970 r. Studium historyczno-socjologiczne na przykładzie Bartoszyc, Olsztyn 2002.

Setlak A., Wojskowa służba kleryków jako jeden ze sposobów zaplanowanej walki systemu socjalistycznego z Kościołem w Polsce [w:] Mundur i sutanna, red. S. Pawłowski, Kraków 1998.

Skrzypek A., Mechanizmy autonomii. Stosunki polsko-radzieckie 1956-1965, Pułtusk 2005.

Skrzypek A., Mechanizmy klientelizmu. Stosunki polsko-radzieckie 1965-1989, Pułtusk 2008.

Skrzypek A., Mechanizmy uzależnienia. Stosunki polsko-radzieckie 1944-1957, Pułtusk 2002.

Śledzianowski J., Ksiądz Czesław Kaczmarek - biskup kielecki 1895-1963, Kielce 2008.

Wawryszko T., Klerycy w wojsku. Wspomnienia ze służby wojskowej 1971-1973, Skołyszyn 2002.

Wilczyński L., Pobór kleryków do wojska jako forma represji władz komunistycznych wobec Kościoła katolickiego. Alumni-żołnierze archidiecezji poznańskiej, „Ecclesia. Studia z Dziejów Wielkopolski” 2017, t. 12.

Zając J., Mundur zamiast sutanny, Kraków 2019.

\section{Internet}

Katalog Instytutu Pamięci Narodowej, http://katalog.bip.ipn.gov.pl/ (dostęp 15 IX 2020 r.).

Kapuściak B., Kontrwywiad wojskowy PRL wobec wizyty Jana Pawła II w kraju w 1979 r., https://przystanekhistoria.pl/pa2/teksty/55464,Kontrwywiad-wojskowy-PRL-wobec-wizyty-Jana-Pawla-II-w-kraju-w-1979-r.html (dostęp 15 IX 2020 r.). 


\section{STRESZCZENIE}

\section{Ba r tos z Ka puści a k, Walka kontrwywiadu wojskowego z Kościołem katolickim. Alumni w „ludowym” Wojsku Polskim w świetle dokumentów Wojskowej Służby Wewnętrznej}

W 1959 r., w związku z wprowadzeniem ustawy o powszechnym obowiązku wojskowym, zaczęto powoływać alumnów do „ludowego” Wojska Polskiego w ramach służby zasadniczej, początkowo rozpraszając ich po licznych jednostkach. Była to forma represji, która według władz komunistycznych miała ukrócić „niepokorne” zachowanie się poszczególnych hierarchów kościelnych. W dalszych latach nastąpiły zmiany w sposobie wcielania kleryków do wojska - zaczęto grupować ich w trzech pododdziałach, co pozwoliło na lepszą indoktrynację prowadzoną przez Główny Zarząd Polityczny Wojska Polskiego, ale przede wszystkim „ochronę” kontrwywiadowczą alumnów organizowaną przez Wojskową Służbę Wewnętrzną.

Początkowo kontrwywiad wojskowy nie radził sobie z werbunkiem kleryków na agentów. Z czasem, przy rozwijającej się współpracy z Departamentem IV MSW (cywilnym pionem antykościelnym), udało się organom WSW lepiej rozwinąć pracę operacyjną w batalionach, gdzie służyli przyszli duchowni. Pomimo częściowej rezygnacji kleryków ze studiów i werbunkowi przez WSW, dzięki staraniom Kościoła katolickiego udało się uratować sporą liczbę młodych alumnów, a wcielanie ich do wojska wzmocniło tylko Kościół, weryfikując już na wstępie przyszłych księży. Ostatecznie rok 1980 przyniósł zakończenie akcji powoływania alumnów do Sił Zbrojnych PRL. Jedna z licznych akcji władz komunistycznych przeciwko Kościołowi katolickiemu okazała się nieskuteczna.

Słowa kluczowe: Wojskowa Służba Wewnętrzna, Główny Zarząd Polityczny WP, służba wojskowa, kleryk-żołnierz, alumni, Kościół katolicki

\section{SUMMARY}

\section{Bartosz Kapuściak, Military Counterintelligence Fight with the Catholic Church. Clerical Students in the Polish „People's” Army in the Light of the Documents of the Internal Military Service}

In 1959, following the introduction of the law on universal military service, seminarians were conscripted into the Polish „People's” Army as part of compulsory service, initially dispersing them into numerous units. This was a form of repression which, according to the communist authorities, was supposed to curb the „unruly” behavior of individual church hierarchs. In the following years, there were changes in the way clerical students were dispersed in the army - they started to be grouped into three subunits, which allowed for better communist indoctrination led by the Main Political Directorate of the Polish Army, but above all for the counterintelligence "protection" of the seminarians organized by the Internal Military Service (IMS).

Initially, military counterintelligence did not do well with recruiting seminarians as agents. With time, as the cooperation with Department IV of the Ministry 
of Interior (civil anti-church department) was developing, the IMS authorities managed to improve their operational work in the battalions where future clergymen served. Despite the partial resignation of clerical students from their studies and recruitment amongst them by IMS, thanks to the efforts of the Catholic Church a large number of young seminarians were saved, and their conscription into the army only strengthened the Church by verifying future priests through their military service at the very beginning. Eventually, year 1980 put an end to the conscription of seminarians into the Armed Forces of the People's Republic of Poland. One of the numerous actions of the communist authorities against the Catholic Church proved to be ineffective.

Keywords: Internal Military Service, Main Political Board of the Polish Army, military service, clerical student-soldier, seminarians, Catholic Church

\section{АННОТАЦИЯ}

\section{Бартош Капущчак, Борьба военной контрразведки с католической церковью. Семинаристы в „народном” Войске Польском в свете документов Внутренней Военной службы}

В 1959 г., в связи с введением закона о всеобщей воинской повинности, в основной состав „народного” Войска Польского начали призывать семинаристов, поначалу распределяя их по многочисленным подразделениям. Это была форма репрессии, которая, по мнению коммунистических властей, должна была положить конец „мятежному” поведению отдельных церковных иерархов. В последующие годы произошли изменения в методе набора семинаристов в армию: их начали распределять по трем подразделениям, что привело не только к улучшению коммунистической индоктринации, проводимой Главным политическим советом Войска Польского, но и-прежде всего-к появлению „охраны” семинаристов контрразведкой, организованной Внутренней Военной Службой.

Изначально военная контрразведка не справлялась с вербовкой семинаристов в качестве агентов. Со временем, при развивающемся сотрудничестве c IV департаментом Министерства внутренних дел (гражданским антицерковным органом), отделам Внутренней Военной Службы удалось развернуть операционную работу в батальонах, где служили будущие духовники. Несмотря на частичный отказ семинаристов от учебы и частичное их вербование, благодаря стараниям католического Костёла удалось спасти большую часть молодых семинаристов, а их присоединение к армии лишь укрепило Костёл, ибо проверка будущих священников проходила уже на этапе службы. В итоге в 1980 г. завершилась акция по зачислению семинаристов в Вооруженные силы Польской народной республики. Одна из крупнейших акций коммунистических властей против католического Костела оказалась неэффективной.

Ключевые слова: Внутренняя Военная Служба, Главный политический совет Войска Польского, воинская служба, семинарист-солдат, семинаристы, католический костёл 